\title{
Long bone histology and microanatomy of Placodontia (Diapsida: Sauropterygia)
}

\author{
Nicole Klein ${ }^{1,5}$, Alexandra Houssaye ${ }^{2}$, James M. Neenan ${ }^{3,4}$, Torsten M. Scheyer ${ }^{3}$ \\ ${ }^{1}$ Staatliches Museum für Naturkunde Stuttgart, Rosenstein 1, 70191 Stuttgart \\ ${ }^{2}$ UMR 7179 CNRS/Muséum National d'Histoire Naturelle, Département Ecologie et Gestion de la Biodiversité, 57 \\ rue Cuvier CP-55, 75000 Paris, France \\ ${ }^{3}$ Paläontologisches Institut und Museum, Universität Zürich, Karl Schmid-Strasse 4, CH-8006 Zurich, Switzerland \\ ${ }^{4}$ The Function, Evolution and Anatomy Research (FEAR) Lab; School of Environmental and Rural Science; Univer- \\ sity of New England, Armidale NSW 2351, Australia \\ ${ }^{5}$ Email: nicole.klein@smns-bw.de
}

Key words: bone mass increase, bone tissue types, extinct marine reptiles, high growth rates, PCA, swimming capabilities, Triassic

\begin{abstract}
Placodontia, an enigmatic group of durophagous and in part heavily armoured animals, were members of Sauropterygia, the most diverse and successful group of Mesozoic marine reptiles. Microanatomy and histology of long bones of several armoured and non-armoured Placodontia were studied, covering most of their taxonomic breadth, to elucidate the paleoecology, physiology, and lifestyle of its members. Results reveal an unexpected and not phylogenetically or stratigraphically related disparity of microanatomical and histological features for the group. The non-armoured Paraplacodus and the heavily armoured Psephoderma grew with lamellar-zonal bone tissue type, which is typical for modern sauropsids. In the former, the tissue is nearly avascular surrounding a compacted medullary region, whereas in the latter, the lamellar-zonal bone tissue is vascularized framing a large open medullary cavity and a perimedullary region. Armoured Henodus and Placodontia indet. aff. Cyamodus as well as non-armoured Placodus exhibit a reduced medullary cavity and grew with highly vascularized plexiform to radiating fibro-lamellar bone. Several long bones of Placodontia indet. show circumferential fibro-lamellar bone and can be distinguished into two groups on the basis of microanatomical features. In addition, all bones that grew with fibro-lamellar bone show locally primary spongeous-like architecture and had secondarily widened primary osteons throughout the cortex, resulting in a secondarily spongeous tissue. The highly vascularized fibro-lamellar bone of these Placodontia indicates growth rates comparable to that of open marine ichthyosaurs. Differences in microanatomy and bone histology as expressed by a principal component analysis, thus clearly indicate different paleoecologies, including differences in lifestyle and swimming modes and capabilities in Placodontia. This would have reduced competition in the shallow marine environments of the Tethys and might be a key to their success and diversity. A certain developmental plasticity among the studied placodonts is interpreted as response to different environmental conditions as is obvious from inter- and intraspecific histological variation. Most striking is the difference in life history strategy in armoured Psephoderma and non-armoured Paraplacodus when compared to armoured
\end{abstract}

Henodus, Placodontia indet. aff. Cyamodus, non-armoured Placodus, and Placodontia indet. Bone tissue of Psephoderma and Paraplacodus indicates low growth rates and a low basal metabolic rate, as many modern sauropsids have such as the marine iguana, whereas the others grew with extremely fast growth rates, more typical for birds and mammals, indicating an increased basal metabolic rate.

\section{Contents}

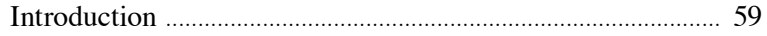
Previous works on long bone histology and microanatomy of placodonts ...................................................... 63

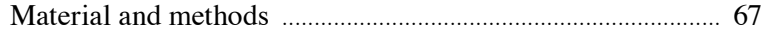

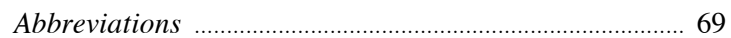

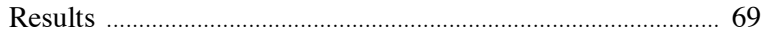

Microanatomical description .............................................. 69

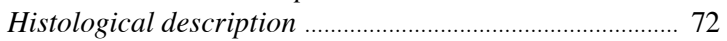

Results of the Principal Component Analysis ..................... 75

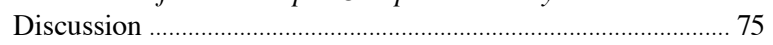

Microanatomical tendencies …………………………......... 75

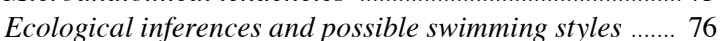

Histological characteristics ................................................ 76

Different bone tissue types and growth strategies ........... 79

Concluding remarks ......................................................... 80

Acknowledgements …………………………………………......... 80

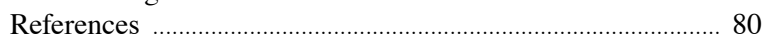

\section{Introduction}

Placodontia were part of the Sauropterygia, a diverse group of diapsid marine reptiles that ranged from the late Lower Triassic until the end of the Cretaceous (Rieppel, 2000a; Motani, 2009). The Triassic radiation included predominately shallow marine forms such as 


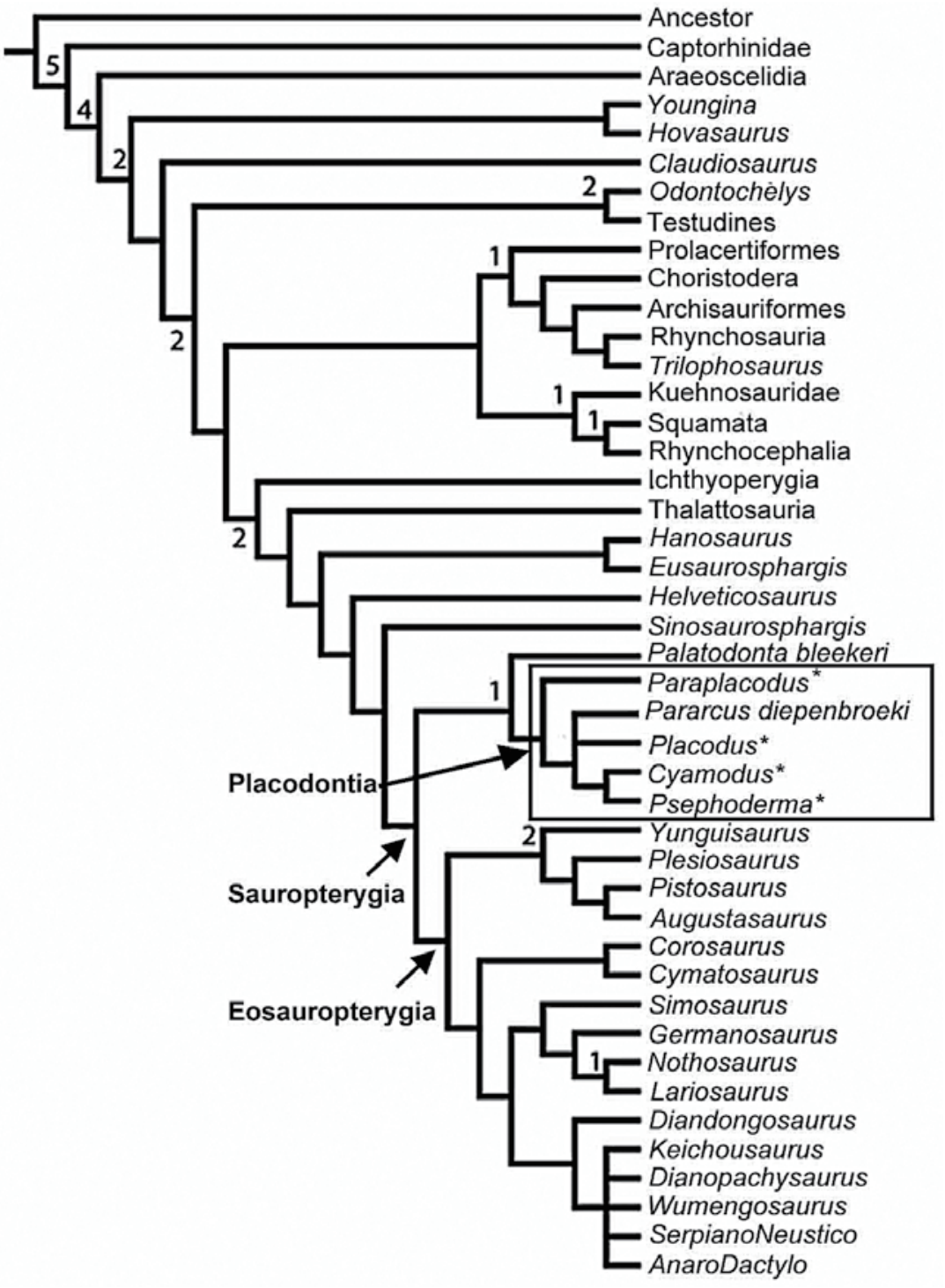

Fig. 1. Phylogenetic relationships within Diapsida, including Sauropterygia and Placodontia. The asterisks mark the histologically studied members of Placodontia. Cladogram modified from Neenan $e t$ al. (2013) and Klein and Scheyer (2014).
Placodontia, Pachypleurosauria, Nothosauria, and Pistosauria; conversely, the Jurassic and Cretaceous seas were ruled by the open marine Plesiosauria. The latter had a global distribution, whereas most Triassic representatives were largely restricted to epicontinental seas of the Tethys Ocean. Triassic Sauropterygia are notable for having a large variety of ecologies, life histories and feeding strategies, which enabled them to live contemporaneously in the same habitats.

Placodonts were the sister group of Eosauropterygia (Pachypleurosauria, Nothosauria, Pistosauria; Rieppel, 1994) (Rieppel, 2000a; Neenan et al., 2013) (Fig. 1), and they first appeared in the fossil record in the early Anisian (Lower Muschelkalk) of the Germanic Basin
(Hagdorn and Rieppel, 1999; Neenan et al., 2013). Beyond the Germanic Basin they occurred along the epicontinental coasts of the western Tethys (Rieppel, 2000a: circummediterranean Muschelkalk localities in Spain, Tunisia, Israel, and Saudi Arabia) and can also be found in the Anisian, Ladinian, and Carnian of China (Li, 2000; Li and Rieppel, 2002; Jiang et al., 2008; Zhao et al., 2008). Placodontia vanished from the fossil record of the Germanic Basin in the Lower Carnian, but survived in the Alpine Triassic realm until the end of the Late Triassic (Furrer et al., 1992; Renesto et al., 1995; Hagdorn and Rieppel, 1999).

The phylogenetic relationships within Placodontia have repeatedly been tested in recent years, and is 
currently considered to be divided into a non-armoured placodontoid grade and a heavily armoured monophyletic Cyamodontoidea (Rieppel, 2000a, b, 2001; Jiang et al., 2008; Neenan et al., 2013). The placodontoid grade contains at least three taxa (Rieppel, 2000a; Jiang et al., 2008; Klein and Scheyer, 2014). Cyamodontoidea were more diverse, with at least nine genera (e.g. Rieppel, 2000a, b, 2001; Zhao et al., 2008).

Placodonts shared some unique morphological features such as a massive, akinetic skull, and a reduced but specialized dentition, enabling a durophagous diet (summarized in Scheyer et al., 2012; Neenan et al., 2014). According to Hagdorn and Rieppel (1999), all placodonts with the exception of Henodus Huene, 1936 are exclusively found in marine sediments, and their occurrence was strongly related to the availability of shelly prey items. Most Cyamodontoidea showed numerous armour plates (osteoderms) fused into one or two dorsal shields, and in some cases, an additional ventral armour shield (Rieppel, 2002; Scheyer, 2007, 2010). Conversely, the placodontoid Paraplacodus Peyer, 1931 lacked any kind of armour and Placodus Agassiz, 1833 showed only a single row of osteoderms along its vertebral column (Rieppel, 1995, 2000a, b; Jiang et al., 2008). While the postcranial anatomy of Paraplacodus and Placodus is reasonably well known (e.g. Drevermann, 1933; Rieppel, 1995, 2000a, b, 2002; Jiang et al., 2008), the postcranial morphology of many cyamodontoids is only partly understood due to obscuring dermal armour, and the fact that they are commonly embedded in large slabs of rock matrix.

Placodus is the best-known placodontoid so far. Due to its cylindrical, sea cow-like body shape, Placodus has always been interpreted as a slow bottom walker that needed a heavy skeleton to act as ballast, allowing it to walk/stay on the seafloor when feeding (e.g. Vogt, 1983; Westphal, 1988; Rieppel, 1995; Scheyer et al., 2012). Despite its occurrence in solely marine sediments (Hagdorn and Rieppel, 1999) some authors consider the lifestyle of Placodus as not being fully marine (aquatic) but as amphibious, similar to that of the extant marine iguana Amblyrhynchus cristatus Bell, 1825 from the Galapagos Islands (Westphal, 1988) that only enters the sea for feeding. The main reason for this is the lack of gross morphological specialization for an aquatic life in the Placodus skeleton (Carroll, 1988; Westphal, 1988). Placodus limbs are not specially adapted for swimming and it is assumed that Placodus was still able to walk on land (Vogt, 1983; Carroll, 1988). Rieppel (1995: 38) stated that 'the skeletal structure of Placodus clearly indicates a durophagous in- habitant of coastal stretches and shallow seas'. An amphibian lifestyle for Placodus was also hypothesized based on the analysis of humerus microstructure by Canoville and Laurin (2010; please note that the sample they used is not undoubtedly assignable to a certain placodont taxon). However, the streamlined body, stiff vertebral column as shown by hyposphen and hypantrum processes, as well as the long and laterally flattened tail of Placodus clearly indicates certain swimming capabilities (Vogt, 1983; Westphal, 1988; Rieppel, 1995). Additionally, Neenan and Scheyer (2012) concluded that the alert head position of Placodus was ideally suited for feeding in an aquatic environment. Vogt (1983) and Westphal (1988) considered Placodus to be an axial swimmer whereas Braun and Reif (1985) identified Placodus as a subcarangiform swimmer. Despite divergences concerning its mode of locomotion, there is a consensus that Placodus was in any case a slow and not very active swimmer. Based on morphology, Westphal (1988) concluded long diving capabilities for Placodus due to movable ribs and a large ribcage volume. This was later confirmed by other authors who studied bone histology and microanatomy in a placodont humerus; documenting that bone mass increase would have counteracted an increased oxygen store (e.g. Buffrénil and Mazin, 1992; Taylor, 1994; Houssaye, 2009).

The heavily armoured cyamodontoids have a dorsoventrally flattened and laterally extended body, reminiscent of the shape and morphology of flat aquatic turtles, such as snapping turtles (Chelydridae) or the mata mata (Chelus fimbriatus). Another hypothesis states that they buried themselves in sand or gravel on the seafloor, like rays (Mazin and Pinna, 1993; Renesto and Tintori, 1995) or soft shelled turtles (Ernst and Barbour, 1989). The cyamodontoid armour and the turtle shell evolved convergently and are only superficially similar (Scheyer, 2010), because the armour of placodonts is not connected to the underlying postcranial skeleton. In Cyamodus hildegardis Peyer, 1931 for example, the armour can be divided into a main carapace, a pelvic shield, and tail armour (Scheyer, 2010).

The study of bone tissues of extinct vertebrates reveals insights into growth rates and thus into their metabolism and physiology (e.g. Bakker, 1980; Ricqlès, 1983, 1992; Padian and Horner, 2004; Padian et al., 2004; Montes et al., 2007). From the preserved growth record, growth patterns and life history strategies can be deduced (e.g. Castanet et al., 1993; Buffrénil and Castanet, 2000; Sander and Klein, 2005; Sanchez et al., 2010; Hugi and Sánchez-Villagra, 2011; Köhler et al., 

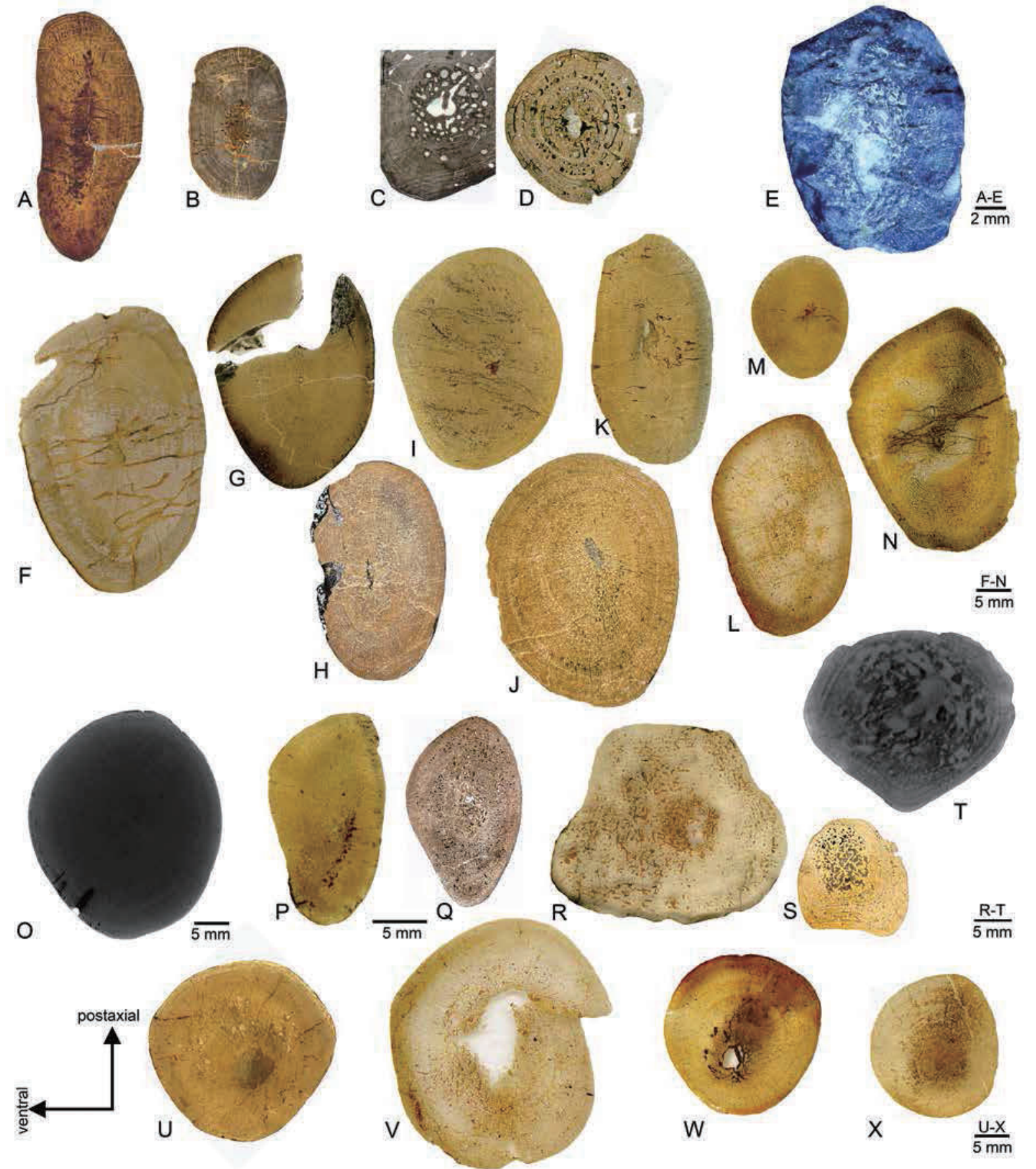

W

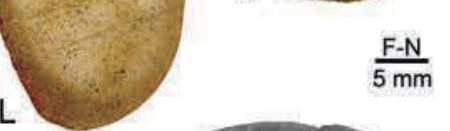

$\frac{\mathrm{F}-\mathrm{N}}{5 \mathrm{~mm}}$
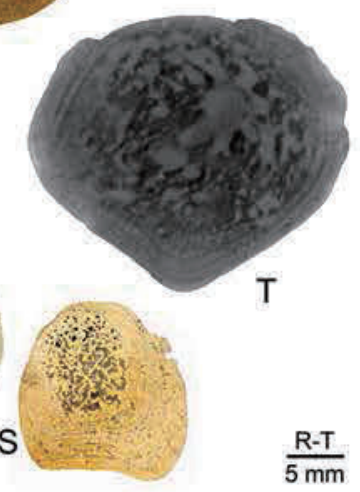

Fig. 2. Photographs of cross sections of sampled bones. A, Cross section of humerus and B, Femur of Paraplacodus broilii (PIMUZ T5845). C, Cross section of humerus (PIMUZ A/III 1476) and D, Femur (PIMUZ A/III 0735) of Psephoderma alpinum. E, Photograph of a breakage at midshaft of Henodus (GPIT/RE/7289). F-M, Cross sections of Placodontia indet. aff. Cyamodus sp. humeri. F, SMNS 59831. G, MHI 2112-6. H SMNS 15891. I, SMNS 54569. J, SMNS 15937. K, SMNS 54582. L, MHI 697. M, MHI 1096. N, Cross section of a humerus of the marine reptile Horaffia kugleri (MHI 2112-4). O, Micro-CT image of the cross section of a humerus (SMNS 59827) assigned to Placodus gigas (Vogt, 1983; Rieppel, 1995). P-X Cross sections of humeri and femora of Placodontia indet. P, humerus MB.R. 454. Q, humerus IGWH 9. R, femur SMNS 84545. S, femur IGWH 23. T, Micro-CT image of the cross section of placodont femur MB.R. 965. U, femur MB.R. 961. V, femur MB.R. 814.2. W, femur MB.R. 812. X, femur SMNS 54578. For locality information and stratigraphic age see Table 1. 

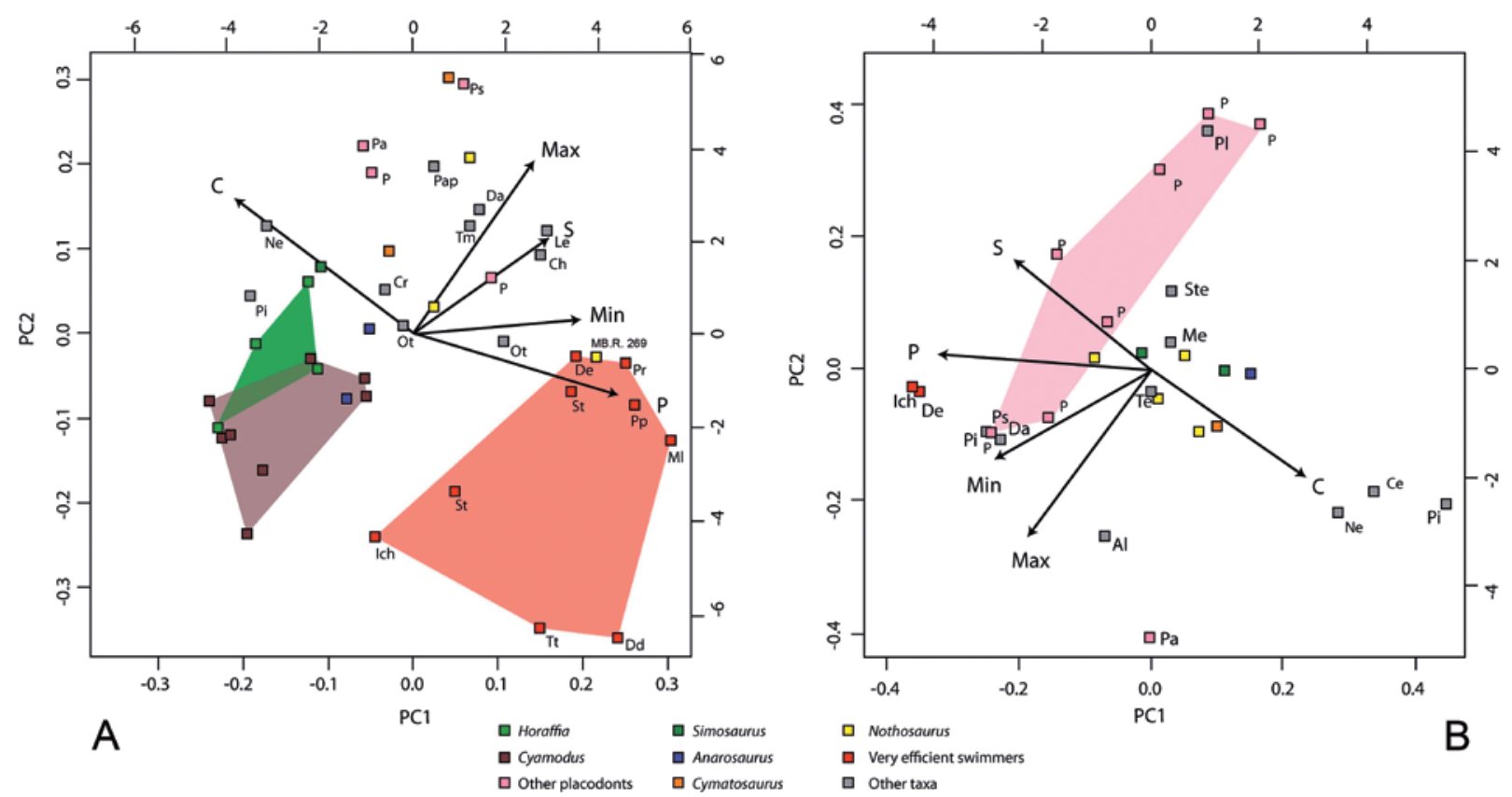

Fig. 3. Microanatomical clusters obtained by Principal Component Analysis (PCA). Graphs showing the distribution of the variance in the humerus and femur sections of modern and extinct aquatic taxa for which bone profiler values were obtained (see S3). The comparative taxa are included to observe, in addition to the placodont diversity, the distribution of Placondontia within aquatic taxa. A, based on humeri. B, based on femora. Abbreviations for the taxa in the PCA graphs as in (S3).

2012; Chinsamy Turan, 2012; Griebeler et al., 2013). The two main trends in life history strategies in extant vertebrates can be summarized-though largely simplified-as lamellar-zonal bone tissue vs. fibro-lamellar bone tissue. Both tissue types seem to be linked to a certain metabolism (poikilotherms vs. homoeotherms; see e.g. Houssaye, 2012). Bone microstructure (i.e., bone compactness, occurrence and size of the medullary cavity, presence of perimedullary region, spongeousor trabecular-like organization, vascularity, etc.) has shown to reflect lifestyle (e.g. Canoville and Laurin, 2010; Houssaye et al., 2010, 2014, Dumont et al., 2013; Quemeneur et al., 2013) and can indicate ecological preferences (e.g. Buffrénil et al., 1987, 1990; Laurin et al., 2004, 2007, 2011; Germain and Laurin, 2005; Hayashi et al., 2013; Houssaye et al., 2013).

It is the aim of the current paper to describe and compare long bone histology and microanatomy of armoured and non-armoured placodont taxa and to address and compare their lifestyles in a phylogenetic framework. The following questions will be addressed: since our placodont sample spans most of the stratigraphical range of the group, can evolutionary stasis or changes/trends be identified? As the samples originate from various localities of the Germanic Basin (shallow marine environments) and of the Alpine Triassic (shallow to open sea environments), can histology be linked to habitat preferences? Can histological characteristics of isolated long bones be used for taxonomic assignment to a group? If so, this would increase the morphological knowledge of placodonts as was done before for other Sauropterygia (e.g. Klein, 2010, 2012; Sander et al., 2013).

Previous works on long bone histology and microanatomy of placodonts

Placodont long bone tissue has been previously studied by Buffrénil and Mazin (1992). The humerus sampled and described therein was assigned to Placodus, although this assignment cannot be verified. The humerus that was figured by Drevermann (1933) in his description of Placodus gigas was later identified to belong to a nothosaur (Rieppel, 1995). The skeleton of the complete $P$. inexpectatus is still embedded in sediment, which makes it difficult to address and compare all morphological features of both humeri of that individual (Jiang et al., 2008; NK, pers. obs.). Thus, an unequivocal taxonomical assignment to a certain placodont taxon of the humerus thin sectioned by Buffrénil 


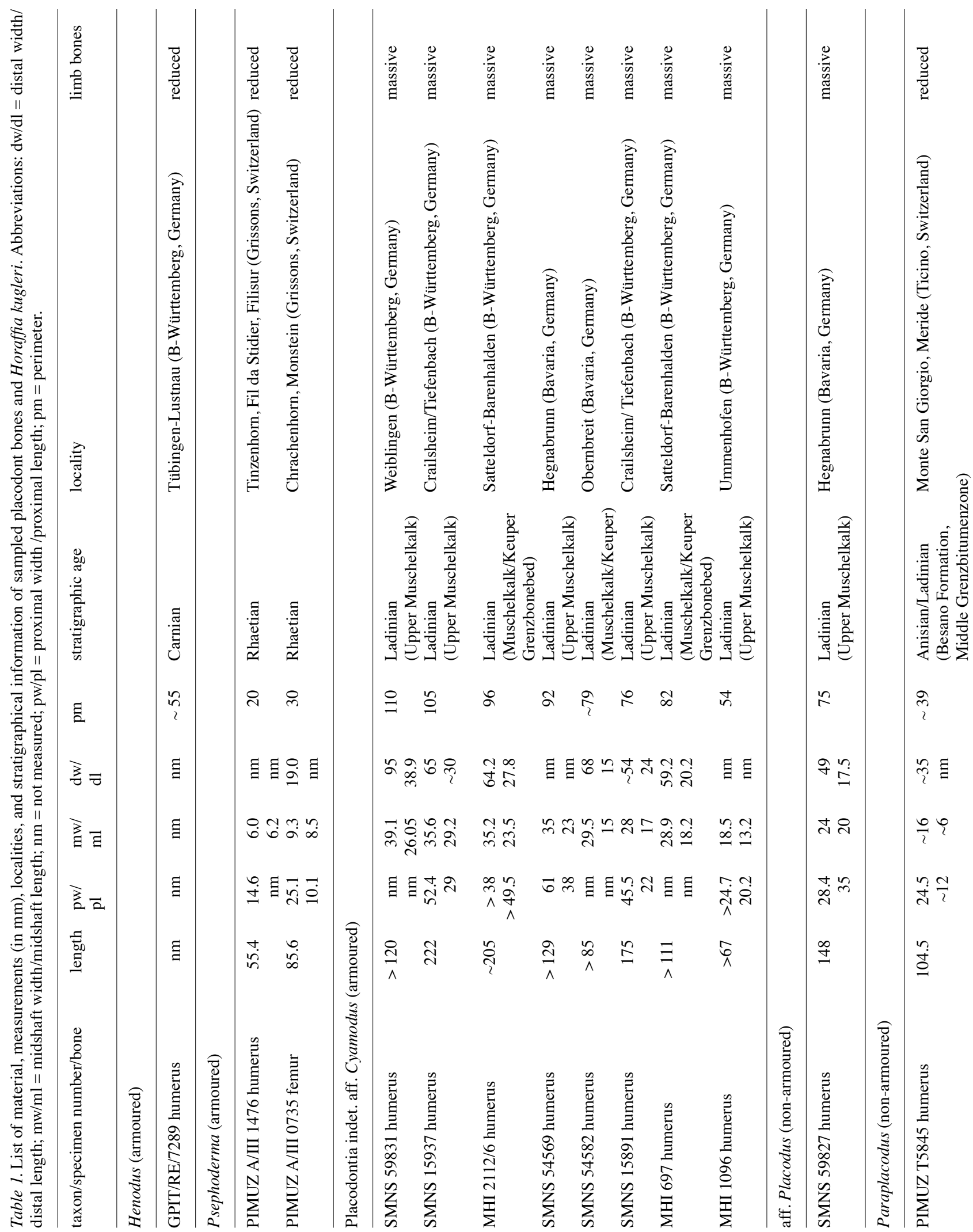




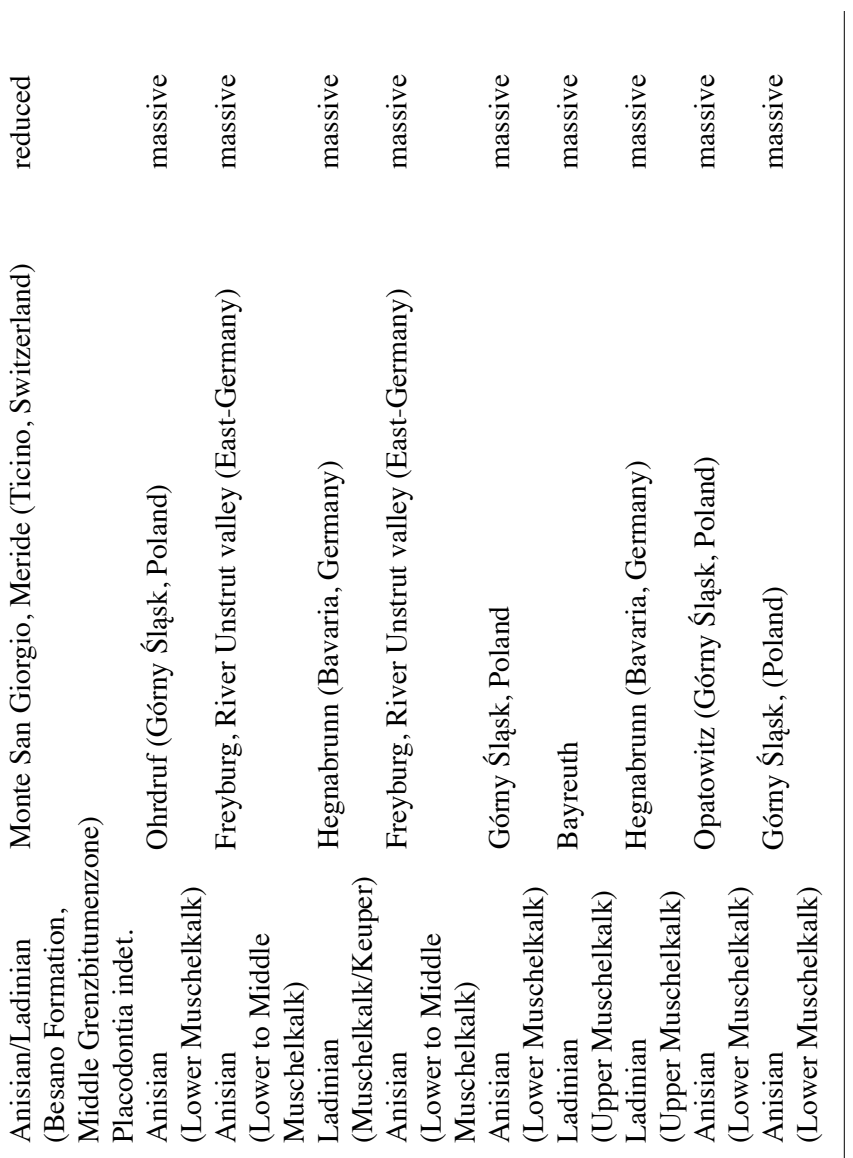

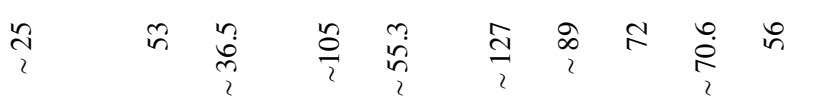

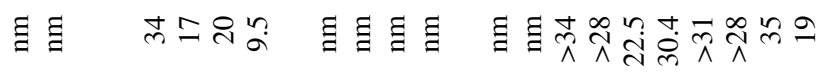

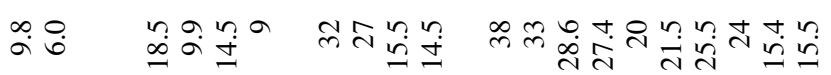

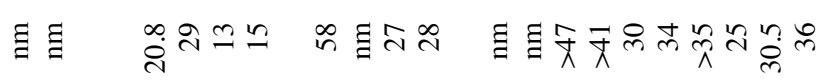

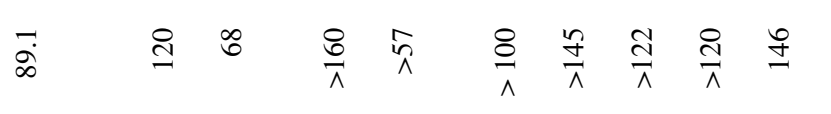

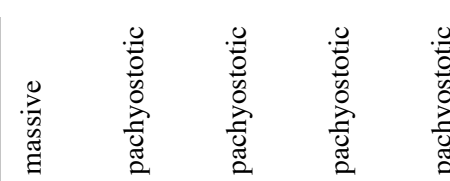
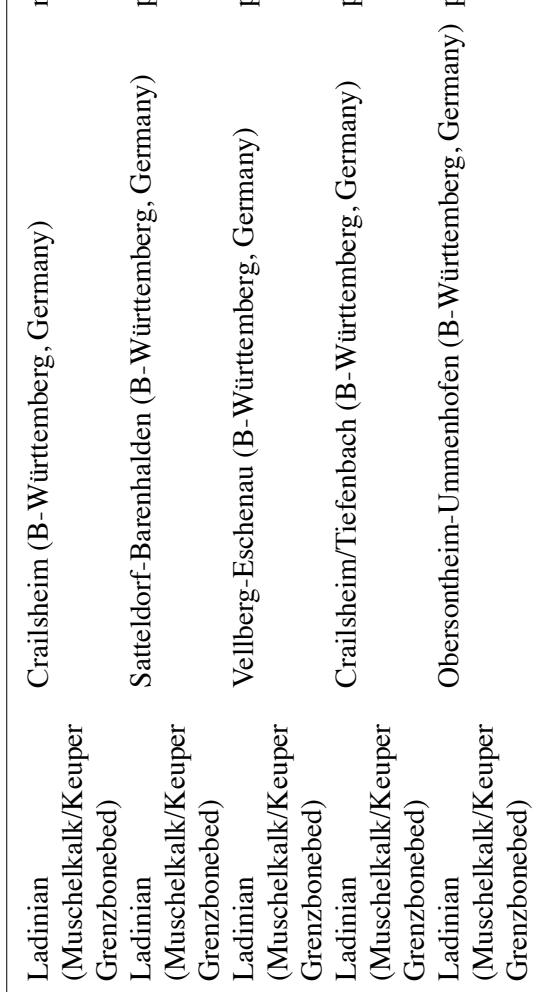

\% in $\approx$ \& $\approx$

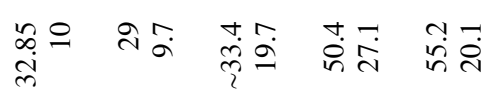

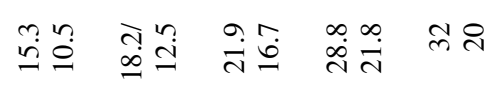

तें

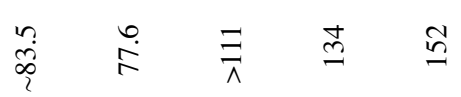

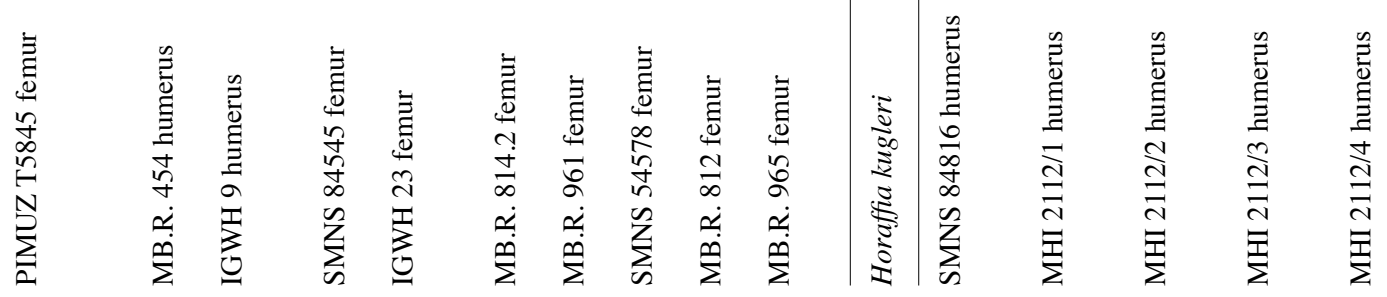




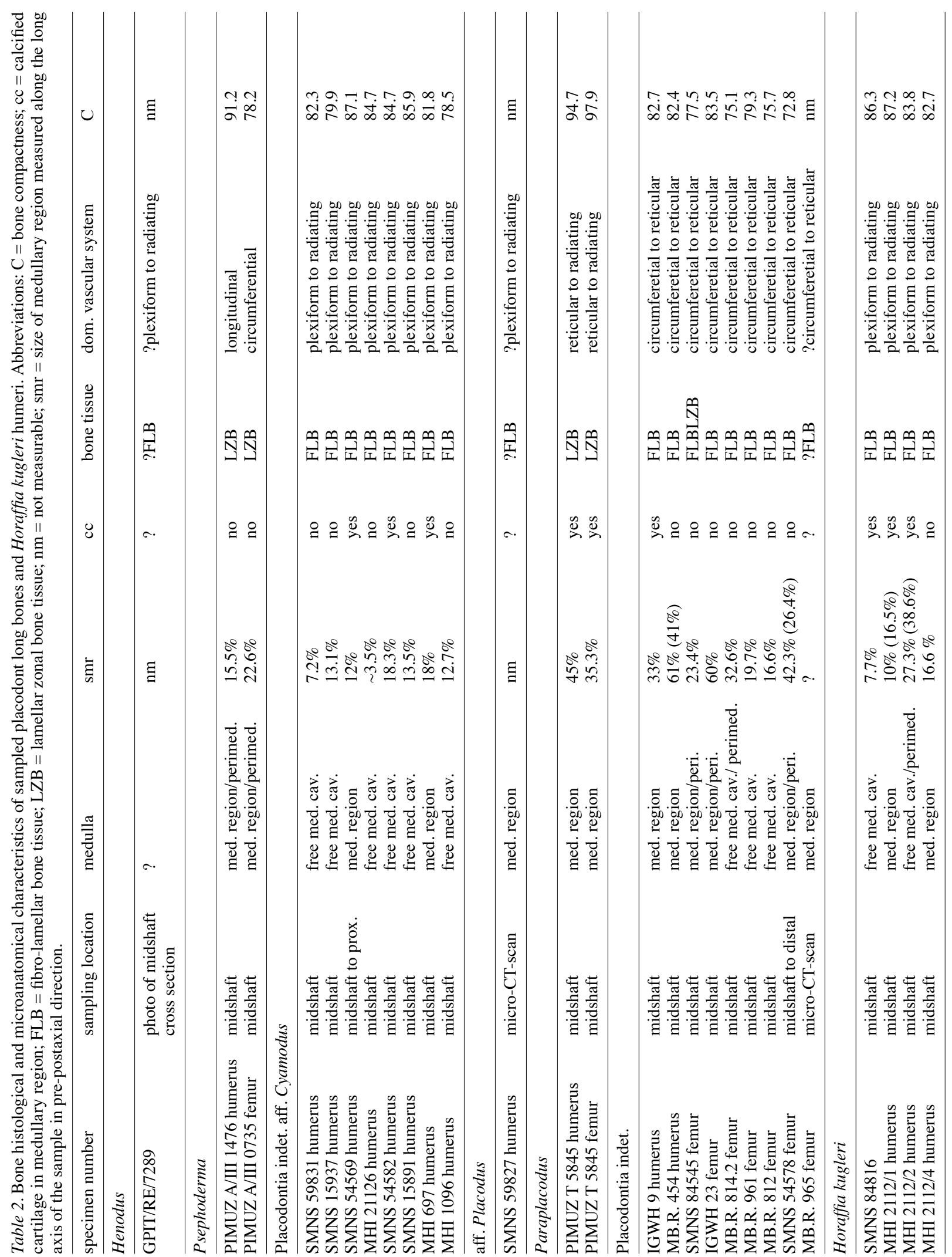


and Mazin (1992) is not possible. Buffrénil and Mazin (1992) characterized the bone tissue as highly vascularized fibro-lamellar bone with a mainly plexiform and reticular vascularization that is in some parts essentially radial. According to Buffrénil and Mazin (1992) inner resorption is very limited. Ricqlès and Buffrénil (2001: 292) also referred to the placodont sample of Buffrénil and Mazin (1992) and characterized the bone as having a "pachyostotic-like condition [resulting] from an absence, or a very poor development of the marrow cavity, instead of a true hyperplasy of periosteal cortices'. Among a sample of various Triassic Sauropterygia Klein (2010) studied two bones assigned to Placodontia indet. that are also included into the current study (IGWH 9, IGWH 23; Table 1) and found that these two bones have the highest growth rates within Sauropterygia. In their quantitative study of humeral microanatomy and lifestyle in amniotes Canoville and Laurin (2010) included the placodont sample of Buffrénil and Mazin (1992) and postulated that this specimen had an amphibious lifestyle. However, they admitted that their inference required to be interpreted with caution, because of an 'apparent contradiction in the various signals' (Canoville and Laurin, 2010: 401). Houssaye (2012), in a review on bone histology of aquatic reptiles with inferences on secondary adaptations to an aquatic life, concluded that the sampled placodont bone from the study of Buffrénil and Mazin (1992), together with some ichthyosaurs and plesiosaurs, showed the highest growth rates within aquatic reptiles.

Klein and Hagdorn (2014) described a new marine reptile taxon, Horaffia kugleri, from the Ladinian of southwest Germany. Its bone histology is described and compared to that of cf. Cyamodus (herein assigned to Placodontia indet. aff. Cyamodus) humeri from the same horizon. Humeri of Horaffia kugleri are pachyostotic whereas those of cf. Cyamodus are not. Humerus histology is essentially similar in both taxa and can be summarized as highly vascularized, plexiform to radiating fibro-lamellar bone tissue with a poorly developed medullary cavity or region, resulting in osteosclerosis. The samples of Horaffia kugleri and cf. Cyamodus described by Klein and Hagdorn (2014) are included in the PCA of the current study.

\section{Material and methods}

For the current study humeri and femora of placodonts were sampled (Fig. 2). These bones usually have most of the primary periosteal bone tissue preserved (e.g. Klein and Sander, 2007) and yield the strongest ecological signal (Canoville and Laurin, 2010). A morphological description for each bone is given in the supplementary information (S1). The material includes armoured and non-armoured Placodontia and spans most of the stratigraphical range of the group from the early Anisian (Middle Triassic) to the Rhaetian (Late Triassic) (Table 1). Paleogeographically, the sample focuses on the western Tethys i.e., on localities from the Germanic Basin and the Alpine Triassic. For further information on localities, as well as the paleogeographical and stratigraphical ranges of placodont taxa, please see Rieppel and Hagdorn (1997), and Hagdorn and Rieppel (1999). A complete list of the bones sampled in this study, with associated measurements, is given in Table 1.

The humeri and femora were photographed, measured, and described using traditional paleontological methods (Table 1; S1-2). When possible, bones were sampled exactly at midshaft by cutting an entire cross section. The importance of exact midshaft samples for comparability was pointed out before (e.g. KonietzkoMeier and Klein, 2013). However, in some specimens, sampling location is slightly proximal or distal to the midshaft on account of bone preservation (see Table 2). The thin sections were produced following standard petrographic methods (Klein and Sander, 2007). Thin sections were then studied and photographed with a Leica ${ }^{\circledR}$ DMLP compound polarizing microscope, equipped with a digital camera (Leica ${ }^{\circledR}$ DFC 420C) and a Leica ${ }^{\circledR}$ DM 750P compound polarizing microscope equipped with a digital Leica ${ }^{\circledR}$ ICC50HD camera. Cross-sections were scanned with an Epson V740 PRO high-resolution scanner (Fig. 2). The bone histological terminology follows Francillon-Vieillot et al. (1990). The size of the medullary cavity/region was measured along the pre-postaxial width of the bones (Table 2).

Some samples were micro-CT scanned with a vltomelxs by GE phoenixlx-ray at the Steinmann Institute of Geology, Mineralogy and Paleontology (StIPB) (Table 2). Image visualization was performed using VGStudio MAX 2.0 software (Volume Graphics $\mathrm{GmbH}$ ) and Adobe Photoshop. CT slices were used to trace vascularity and bone tissue type. However, contrast between bone and the infilling sediment, and resolution were not always sufficient to precisely determine these features.

Scanned pictures of thin sections were transformed into black (vascular spaces) and white (bone) pictures (S4) that were analyzed with the program Bone Profiler (Girondot and Laurin, 2003) (Table 2; Fig. 3; S3). We 

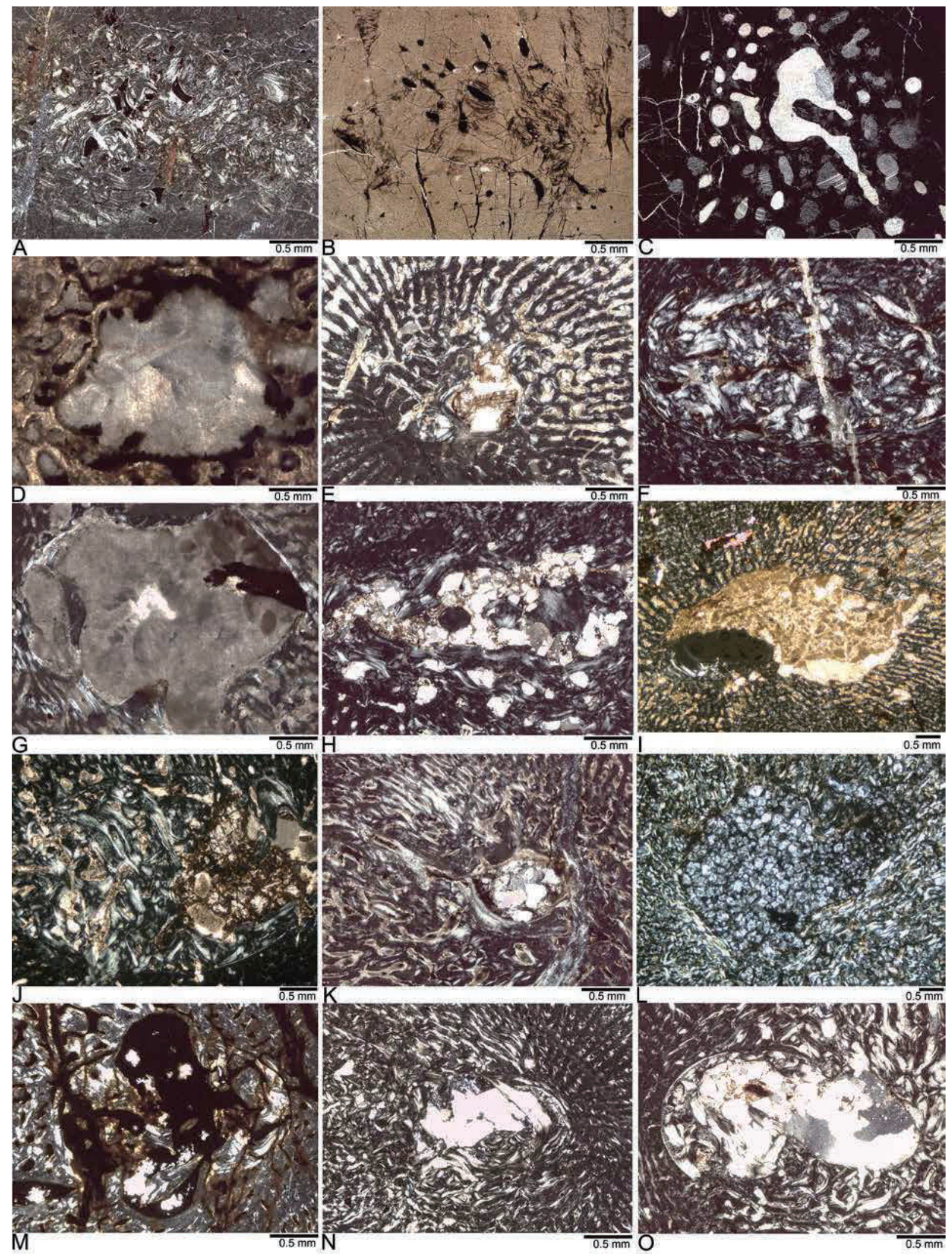
examined five parameters provided by this software to characterize the bone density distribution: $\mathrm{C}, \mathrm{P}, \mathrm{S}, \mathrm{Min}$ and Max. $\mathrm{C}$ is the global bone compactness for the whole sectional area. $\mathrm{P}$, is the relative distance from the center of the section to the point where the most abrupt change in compactness is observed, which is proportional to the size of the medullary cavity. S, is the reciprocal of the slope at the inflection point, generally reflects the width of the transition zone between the cortical bone and the perimedullary region. Min and Max are, respectively, the minimum and maximum asymptotes and thus represent the minimum and maximum bone compactness values in a section. A Principal Component Analysis (PCA) was performed on the Bone Profiler parameters cited above using the statistic software R (R Development Core Team, 2008) in order to explore the distribution of the different taxa in morphospace while optimizing the variance. Various extant and fossil aquatic amniotes (S3) were added to our sample in the PCA.

\section{Abbreviations}

IGWH Institute of Geosciences of the MartinLuther-University Halle-Wittenberg, Germany

MfN (MB.R.) Museum of Natural History, Leibniz Institute for Research on Evolution and Biodiversity at the Humboldt University Berlin, Germany

MHI Muschelkalkmuseum Ingelfingen, Germany

PIMUZ Paleontological Institute and Museum of the University of Zurich, Switzerland

SMNS Stuttgart State Museum of Natural History, Germany

\section{Results}

\section{Microanatomical description}

The humerus and femur of Psephoderma alpinum both have a central free medullary cavity that is surrounded by scattered large erosion cavities (in a perimedullary region), which reach far into the cortex (Table 1; Figs 2C, D; 3C, D). The erosion cavities are mainly roundish to oval shaped. In the humerus, they are randomly organized whereas those in the femur are arranged in circumferential rows. Vascular density is low (Table 2, 3).

The photograph of the midshaft cross section of the Henodus humerus indicates a relatively large medullary region consisting of large cavities and randomly organized trabecles (Table 1; Fig. 2E) surrounding a rather small medullary cavity. The vascular system is dominated by a radial organization and contains longitudinal and radial canals as far as observable. In general, microstructure of Henodus seems to be comparable to that of Placodontia indet. aff. Cyamodus humeri (see below).

Midshaft samples of humeri of Placodontia indet. aff. Cyamodus usually show a small free medullary cavity (Figs 2F-M; 4E-L) that is lined by a thin layer of endosteal bone, those that were not taken exactly at midshaft have a medullary region consisting of small cavities, endosteal bone deposits, and scattered pockets of calcified cartilage (Figs 4F, J). The medullary region is then surrounded by a sharp line, which consists of a very thin layer of endosteal bone. Vascular density in the humeri is poor in the innermost cortex but always high in the middle and outer cortex (Table 2; Figs 2F-M; 4E-L). Contrary to the condition in other vertebrates vascular density increases towards the outer cortex in Placodontia indet. aff. Cyamodus humeri. Long and thick, mainly radial vascular canals forming a primary trabeclelike architecture dominate locally the inner to middle cortex of the pre- and postaxial bone sides. The entire cortex of humeri MHI 1096, SMNS 15937, and SMNS 59831 is spongeous-like in organization: al-

4 Fig. 4. Details of medulla and inner cortex of Placodontia long bones. A, Humerus in polarized light and B, Femur in normal light of Paraplacodus broilii (PIMUZ T5845). The medullary region consists of endosteal deposits with pockets of calcified cartilage in between. In the femur large erosion cavities occur in the centre of the section. C, Humerus (PIMUZ A/III 1476) and D, Femur (PIMUZ A/III 0735) of Psephoderma alpinum both in polarized light. Note that the medullary cavities are surrounded by a distinct perimedullary region. E-L, Placodontia indet. aff. Cyamodus humeri all in polarized light. Except for SMNS 54569 (Fig. 3), which represents a more proximal sample and MHI 697 all midshaft samples exhibit a small free cavity. SMNS 54569 (Fig. 3) and MHI 697 (Fig. 3F) show a medullary region infilled by secondary trabecels, sediment filled cavities, and pockets of calcified cartilage. E, MHI 1096. F, MHI 697. G, SMNS 59831. H, SMNS 15891. I, SMNS 54582. J, SMNS 54569. K, MHI 2112/6. L, SMNS 15937. M-O, Humeri of the marine reptile Horaffia kugleri. Horaffia kugleri has a small free cavity surrounded by a medullary region at midshaft. M, MHI 2112/4. N, SMNS 84816. O, MHI $2112-1$. 

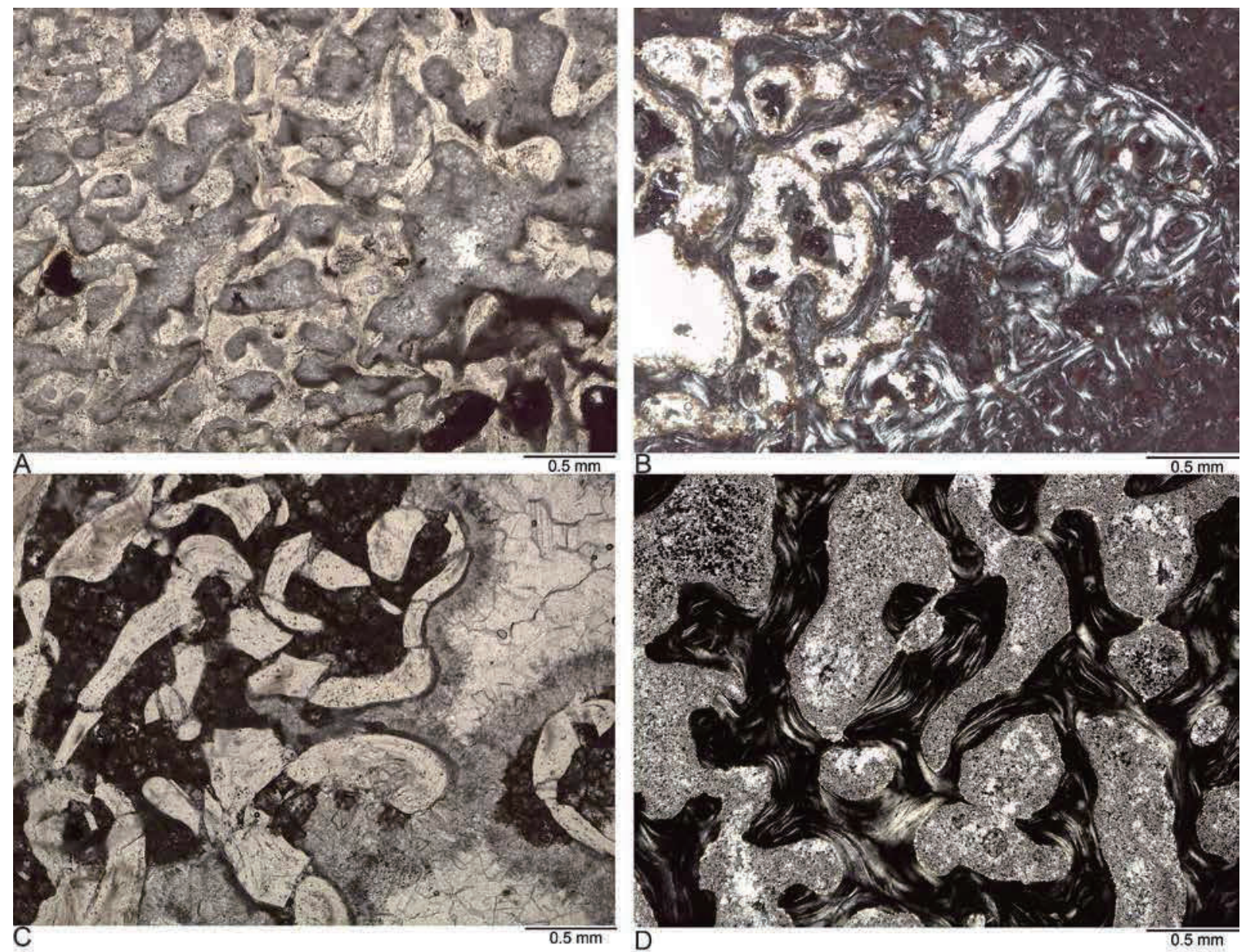

Fig. 5. Details of medulla and inner cortex of Placodontia indet. humeri and femora. All bones have a large medulla consisting of secondary trabecles and large cavities. A, Medulla of humerus MB.R. 454 in normal light. B, Medulla of humerus IGWH 9 in polarized light. C, Medulla of femur SMNS 84545 in normal light. D, Medulla of femur IGWH 23 in polarized light.

though the surface occupied by bony tissues represents much more than $50 \%$ of the cortex surface, the high amount of primary osteons with large vascular spaces confers to the cortex a spongeous aspect (Table 2, 3; Figs 2, 7). In the other samples, the inner cortex can be locally spongeous-like and/or trabecular-like. All samples share a spongeous-like organization of the outer cortex (Fig. 7). The spongeouslike organization is the result of locally primary spongeous and trabecular bone and secondarily widened primary osteons.

The midshaft of a humerus (SMNS 59827), which is thought to represent aff. Placodus (Vogt 1983; Rieppel 1995) was micro-CT-scanned. The resolution of the resulting pictures is poor, which is however often the case for Muschelkalk samples (NK, pers. obsv.). A medullary cavity in the center of the cross section cannot be identified and the organization seems to be rather loose, most likely indicating a medullary region (Fig. 2O). The vascular system resembles that of humeri of Placodontia indet. aff. Cyamodus. The outer cortex clearly shows large vascular canals (Fig. 2O).

The humerus and femur of Paraplacodus broilii both have a medullary region that is densely packed with endosteal deposits and pockets of calcified cartilage (Figs 2A, B; 4A, B). The bone tissue is nearly avascular (Table 2; Figs 6C, D).

The medullary region of humerus MB.R. 454 (Placodontia indet.) is very large (Figs 2P, 5A). The area consists of thin secondary trabecles surrounding intertrabecular spaces. Humerus IGWH 9 (Placodontia 

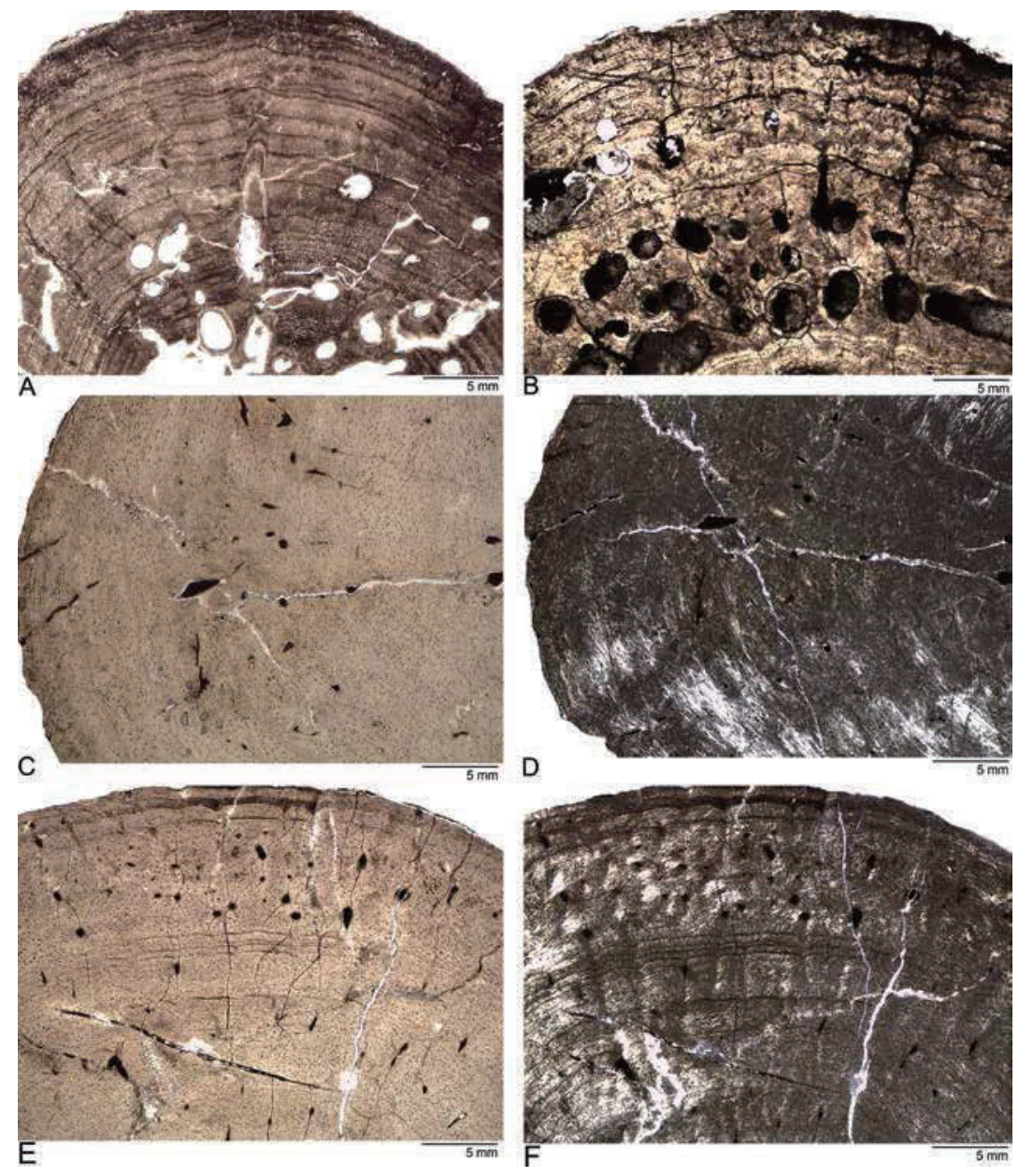

Fig. 6. Histological details of armoured Psephoderma and non-armoured Paraplacodus. A, Detail of lamellar-zonal bone tissue of Psephoderma humerus (PIMUZ A/III 1476) and B, femur (PIMUZ A/III) in normal light. Note the large erosion cavities of the perimedullary region in both bones. C, Detail of lamellar-zonal bone tissue of Paraplacodus humerus (PIMUZ T5845) in normal light and $\mathrm{D}$, in polarized light. E, Detail of lamellar-zonal bone tissue of Paraplacodus femur (PIMUZ T5845), normal light and $\mathrm{F}$, in polarized light. indet.) also shows a large medullary region and a trabecle-like architecture at the postaxial bone side (Figs 2Q, 5B). The medullary region is filled by endosteal deposits. Vascular density is moderate (MB.R. 454) or high (IGWH 9) (Table 2). Bone compactness increases towards the outer cortex in both samples.

Femora IGWH 23 and SMNS 84545 (both Placodontia indet.) both have a large medullary region that consists of several generations of secondary trabecles (Fig. 5C, D). Please note that the cortex is incomplete in IGWH 23 at the dorsal and preaxial bone sides due to preservation (Fig. 25). Ventrally, large irregularly shaped cavities are aligned in circumferential rows. The cortex is in both scattered with randomly shaped and oriented large cavities, resulting in a spongeouslike tissue (Fig. 2R, S).

Midshaft sections of placodont femora MB.R. 814.2, MB.R. 961, and MB.R. 812 (Figs 2U, V, X) have an off-centered free medullary cavity, which corresponds to a medullary region in the more distal section SMNS 54578 (Fig. 2W). The medullary region in non-midshaft sample SMNS 54578 consists of secondary trabecles. Vascular density in all specimens is high (Table 2). The vascular canals have undergone resorption resulting in the formation of large cavities. All samples show locally (mainly at the dorsopostaxial bone sides) a radial or irregularly formed trabecle-like architecture and locally spongeous-like tissue. Vascular density decreases towards the outer cortex. One placodont femur (MB.R. 965) was micro-CT-scanned. The quality of the resulting pictures documents a similar microstructure as was described for the femora above: most of the cross section shows a large medullary region followed by spongeous-like tissue in the inner cortex (Fig. 2T). Locally a trabecle-like architecture is visible. Only the outer cortex region is compact. 

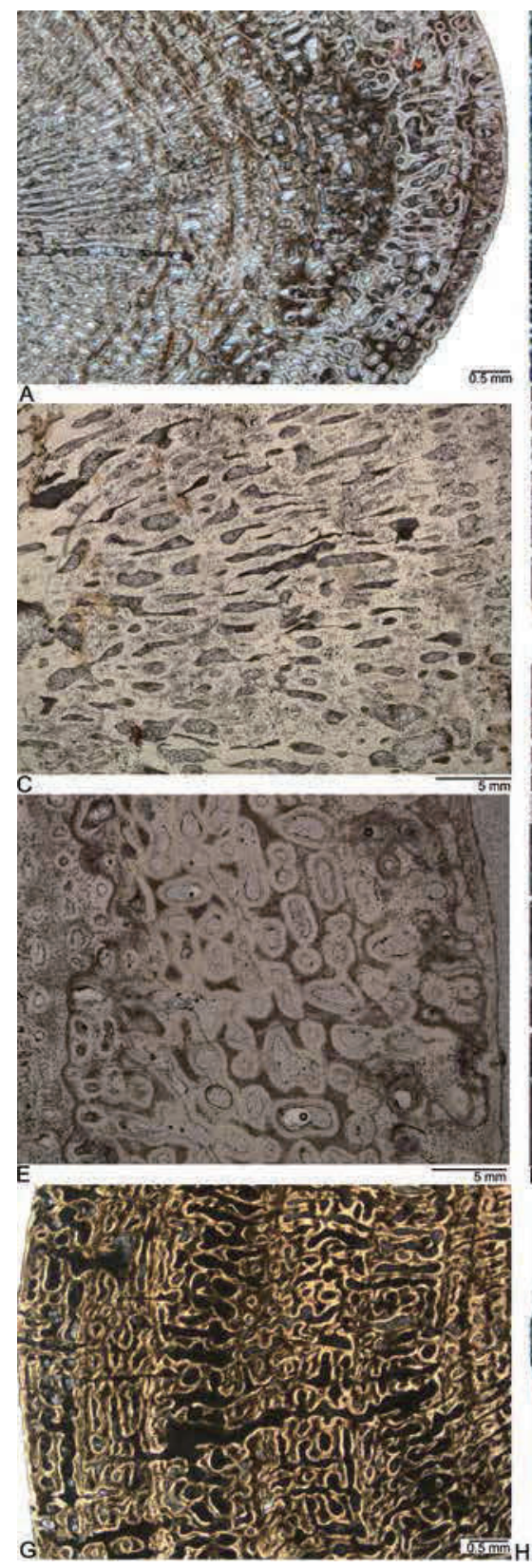
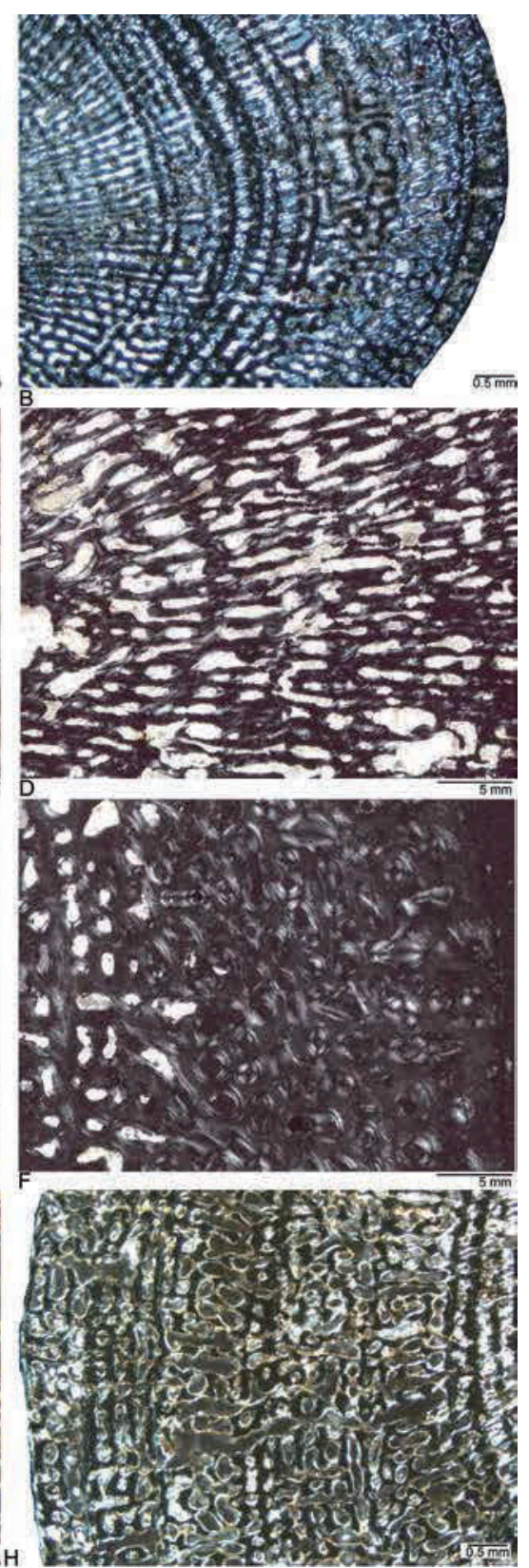

Fig. 7. Histological details of humeri of Placodontia indet. aff. Cyamodus. A, Detail of the postaxial bone side of humerus MHI 1096 in normal light and B, in polarized light. The inner cortex shows a spongeous tissue and a radial trabeclelike structure. In the middle cortex vascular canal organization changes to longitudinal and mainly irregular vascular spaces. The spongeous tissue continues until the outermost cortex. Note the fibrolamellar bone tissue between the radial trabecular spaces. C, Detail of spongeous inner cortex with radial, longitudinal, and irregularly formed vascular canals of humerus SMNS 54582 in normal light and $\mathrm{D}$, in polarized light. E, Detail of outer cortex with secondarily widened longitudinal primary osteons of humerus SMNS 54569 in normal light and F, in polarized light. G, Detail of humerus SMNS 15937 in normal light and $\mathrm{H}$, in polarized light. The middle to outer cortex shows a trabecle-like structure with radial, circumferential, reticular, and irregular vascular canals. Vascular canals are connected by anastomosis. The entire cortex contains secondarily widened vascular canals.

\section{Histological description}

The bone tissue of the humerus and femur of Psephoderma alpinum is altered by diagenesis in both samples and its nature is obscured under cross-polarized light. Scattered erosion cavities, which are thinly lined by lamellar bone, indicate remodelling. Primary bone tissue seems to consist solely of lamellar bone and did not show any osteocyte lacunae. Both bones show only a few longitudinal vascular canals in their outer cortex that are thinly lined by lamellar bone, and so correspond to primary osteons (Fig. 6A). In the humerus they occur at the postaxial side and in the femur at the ventral side (Fig. 6B). The cortex is divided by growth marks (Klein et al., unpubl. data). The bone tissue type can be summarized as lamellar-zonal bone.

The cortex of Henodus shows mainly longitudinal and radial vascular canals that are arranged in a plexi- 
form to radiating system (Table 2), resembling that of Placodontia indet. aff. Cyamodus humeri. Details of bone tissue cannot be established due to the poor resolution of the micro-CT-scan.

The bone tissue type of Placodontia indet. aff. Cyamodus can be summarized as radiating to plexiform fibro-lamellar bone. Woven bone is typically comprised by lamellar bone. However, the core of woven bone can correspond to parallel-fibred bone based on the extinction pattern under polarized light that is made of coarse and thick fibers, which overlay each other. However, the large, round, and numerous osteocyte lacunae resemble the chaotic arrangement seen in typical woven bone. In the outer cortex of SMNS 59831 osteocyte lacunae are almost flat, and thus more in accordance with typical parallel-fibred bone. All kinds of vascular canals are present: radial, longitudinal, reticular, and circumferential ones. Vascular canals often show a tendency to anastomose. Radial vascular canals in the outer cortex are often connected to the bone surface. Longitudinal vascular canals tend to be lined up in rows whereas radial canals can cross growth marks. Onset of remodelling processes is indicated by local cross cutting and cementing lines are sometimes visible (Fig. 7). In two samples (SMNS 54582, MHI 2112-6) infilled (mature) secondary osteons (sensu Currey, 2002) can occur in the innermost cortex. In the inner cortex, vascular canals are often not or only incompletely lined by lamellar bone representing neither simple vascular canals nor fully developed primary osteons (Fig. 7, S5A-C), which we identify as immature primary osteons (Klein, 2010). The number of fully lined primary osteons increases generally towards the outer cortex. The primary osteons are throughout the entire cortex secondarily widened by successive resorption processes. A thick layer of lamellar bone surrounds the widened primary osteons then, which are however, far away from being infilled, resulting in incomplete or immature secondary osteons (S5, 6). The development of these osteons can impede the observation of the nature of the collagenous wave of the surrounding bone (Figs 7E-H). Bone tissue can locally be obscured by diagenesis (i.e. bacteria and/ or fungal growth) or by a dark permineralization of the bone. Placodontia indet. aff. Cyamodus humeri show an alternation of broad, highly vascularized layers of fibro-lamellar bone (zones) and thin, avascular layers made of highly organized parallel-fibred bone or lamellar bone (annuli) (Klein et al., unpubl. data). No clear increase in bone tissue organization from the inner to the outer cortex is visible except in the medium sized humerus SMNS 54582 (that has in general a higher organized and less vacularized bone tissue) and SMNS 59831, which is the largest sampled bone and the only one that shows lamellar bone in the outermost cortex.

Details of bone tissue of the humerus assigned to Placodontia indet. aff. Placodus (SMNS 59827) cannot be addressed due to the poor resolution of the micro CT-scan. Growth marks are visible in the outer cortex.

The primary bone tissue of the humerus and femur assigned to Paraplacodus broilii is in the inner cortex highly organized parallel-fibred bone that, towards the outer cortex, grades into lamellar bone (Figs 6C, D). Simple longitudinal and radial vascular canals dominate the tissue but immature primary osteons also occur. The entire bone tissue is interspersed by regularly sized, small but round osteocyte lacunae. The cortex is divided by growth marks (Klein et al., unpubl. data). The bone tissue type can be summarized as lamellarzonal bone.

The bone tissue of humeri MB.R. 454 and IGWH 9 (both Placodontia indet.) consists of coarse parallelfibred bone, intermixed with woven bone. Primary osteons are surrounded by lamellar bone, resulting in fibro-lamellar bone tissue (Figs 8A, B). Numerous thick osteocycte lacunae are accumulated in the areas of woven and coarse parallel-fibred bone. Both samples share an increase in organization towards the outermost cortex. Vascular canals are radial, longitudinal, and reticular. They are arranged in a mainly plexiform system and canals are locally lined up in rows. The inner cortex is dominated by immature primary osteons, the outer cortex by fully developed primary osteons. The cortex of MB.R. 454 and IGWH 9 is divided by growth marks (Klein et al., unpubl. data).

In femora IGWH 23 and SMNS 84545 (both Placodontia indet.) the bone tissue consists of fibro-lamellar bone with coarse parallel-fibred and woven bone (Figs $8 \mathrm{C}, \mathrm{D})$. The organization of the bone tissue increases towards the outer cortex. In SMNS 84545, tissue organization is generally higher and the outer cortex is solely made of avascular lamellar bone, except for a few, mainly radial canals that open into the surface. Osteocyte lacunae are small but numerous and accumulated in the areas of woven and coarse parallel-fibred bone. In both, the vascular canals are mainly irregularly/reticularly formed. Some represent immature, others mature primary osteons. In SMNS 84545 vascular canals are largely eroded into irregularly formed cavities. The cortex is in both samples divided by growth marks. Infilled (mature) secondary osteons are rare but can occur in the inner cortex. 

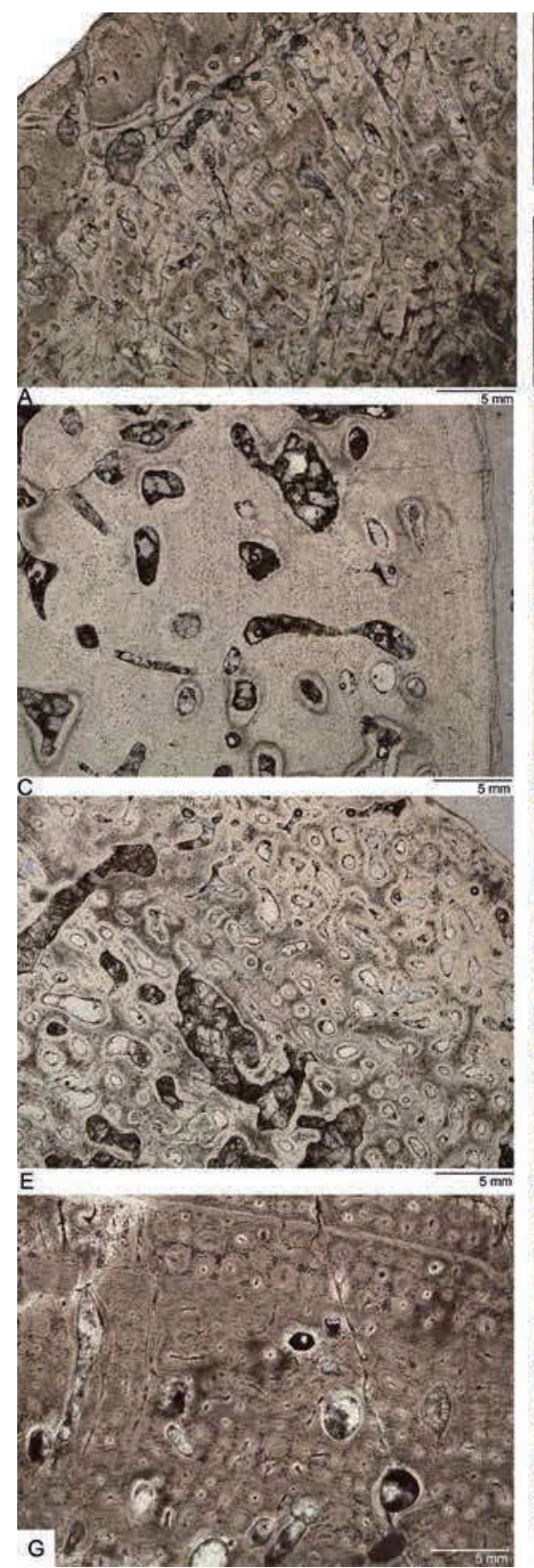
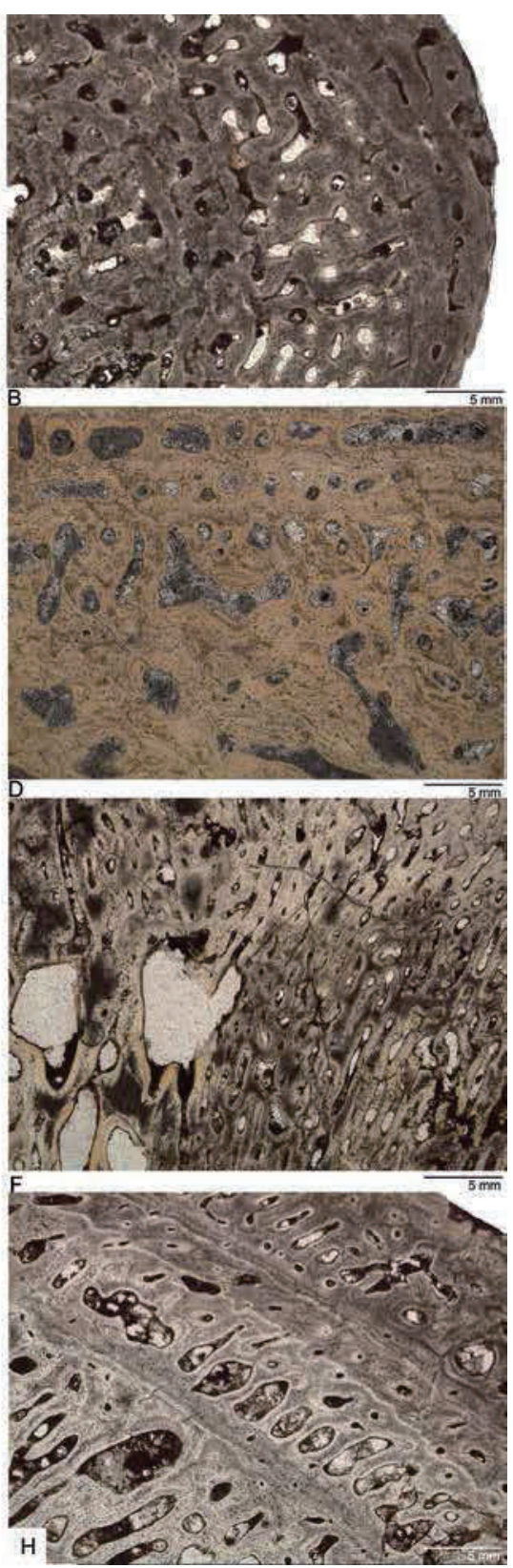

Fig. 8. Histological details of Placodontia indet. humeri and femora. All samples are in normal light. A, Detail of cortex of humerus MB.R. 454. B, Detail of cortex of humerus IGWH 9. C, Detail of cortex of femur SMNS 84545. D, Detail of cortex of femur IGWH 23. The cortex is spread with irregularly formed large vascular canals. E, Detail of cortex of femur SMNS 54578. F, Detail of cortex of femur MB.R. 812. G, Detail of cortex of femur MB.R. 961. H, Detail of cortex of femur MB.R. 814.2. All samples have secondarily widened primary osteons.
The bone tissue in the Placodont indet. femora (MB. R. 814.2, MB.R. 961, MB.R. 812, SMNS 54578) is fibro-lamellar with woven bone or coarse parallelfibered bone and primary osteons surrounded by lamellar bone (Figs 8E-H). The organization of the bone tissue increases towards the outer cortex as the number of vascular canals decreases. In the two largest sampled femora, MB.R. 814.2 and MB.R. 961, the outer cortex is made of lamellar bone. All kind of vascular canals occur (longitudinal, radial, circumferential, and reticular) but longitudinal and radial ones dominate. Locally, vascular canals are lined up in circumferential rows. Most of the vascular canals have been developed into primary osteons but immature primary osteons also occur. Details of the bone tissue of femur MB.R. 965 are not visible in microCT-pictures. All samples show growth marks throughout the cortex (Klein et al., unpubl. data). All Placo- 
dontia indet. bones show locally primary spongeous and trabecular bone and a secondary widening of osteons (Fig. 8; S5, 6).

\section{Results of the Principal Components Analysis}

The PCA of the humeris (see Fig. 3A) shows that the two main axes explain $66.7 \%$ of the variance (46.1 and $20.9 \%$ respectively). $\mathrm{C}$ is the only parameter that negatively contributes to the first axis. Taxa on the first axis essentially discriminate based on $\mathrm{C}$ and $\mathrm{P}$ (projections values of -0.21 and 0.24 , respectively). On the second axis, they essentially discriminate based on Max and $\mathrm{C}$ (projections of 0.20 and 0.16 , respectively). Only $\mathrm{P}$ negatively contributes to the second axis. The graph shows that very efficient swimmers (orange rectangle in Fig. 3A including cetaceans, ichthyosaurs, Prognathodon [Mosasauridae], Dermochelys [leatherback turtle], and the elephant seal Mirounga), together with the nothosaur humerus MB.R. 269, group together notably as a result of their relatively lower compactness. All specimens of Placodontia indet. aff. Cyamodus and Horaffia show a restricted distribution that highlights the strong 'intraspecific' similarity and, moreover, group together, close to the pachypleurosaur $A n$ arosaurus and the Pistosaurus specimens. These taxa clearly distinguish from other less efficient swimmers, notably based on the relatively lower compactness of the cortex and the sharp transition between the compacta and the medullary cavity (with almost no spongeous transition zone). Paraplacodus and Psephoderma are among the taxa showing the highest compactness. Together with the two Placodontia indet. humeri MB R 454 and IGWH 9, they group with the taxa showing a wider transition zone.

The PCA of the femora (see Fig. 3B) results in two main axes jointly explaining $72.4 \%$ of the variance (49.2 and $23.2 \%$, respectively). Only the parameter C positively contributes to the first axis. On this axis, taxa essentially discriminate based on $\mathrm{P}$ (projection of -0.28 ) and, to a lesser extent, $C$ and Min (projections of $+/-0.24)$. Both $\mathrm{S}$ and $\mathrm{P}$ positively contribute to the second axis. On the second axis, taxa essentially discriminate based on Max (projection of 0.264) whereas $\mathrm{P}$ does almost not contribute to this axis. Because of its high compactness and absence of medullary cavity, Paraplacodus is isolated from the other taxa sampled. The other placodonts generally display an open medullary cavity or highly spongeous medullary region and a rather large transition zone. Despite variation in the values of the corresponding parameters, the placodonts sampled (among which no Placodontia indet. aff. Cyamodus) display a rather restricted distribution distinct from the other taxa except Plesiosaurus.

It must be specified that, as Bone Profiler was originally conceived for tubular structures, some peculiar microanatomical organizations obtain aberrant values in the program. It was the case for Paraplacodus bones, notably because compactness was higher in the core than in the outer surface of the bone, so that there was no sigmoid adapted to describe the structure. This was corrected based on an estimate for the analysis. As a result, Paraplacodus should have been much further away from the other taxa in the analysis (Fig. 3).

\section{Discussion}

\section{Microanatomical tendencies}

Within our placodont sample, five main distinct types of microanatomical organization are observed: 1) extremely compact humerus (CI=94.7\%) and femur (CI=97.9\%) with no medullary cavity in Paraplaco$d u s ; 2)$ strongly compact humeri $(78.5 \%<\mathrm{CI}<87.1 \%$; mean value $=83.1 \%$ ) with a small open medullary cavity in Placodontia indet. aff. Cyamodus (no femur was available); 3) strongly compact humerus (CI=91.2\%) with a small medullary cavity surrounded by a spongiosa and a compact outer cortex, and a rather compact femur $(\mathrm{CI}=78.2 \%)$ with a reduced medullary cavity surrounded by a thick spongiosa, with almost no outer compact cortex, in Psephoder$m a$; and 4) humeri and femora with a large medullary region but no open medullary cavity and 5) femora with an open medullary cavity surrounded by a rather large spongiosa.

The extremely compact bones of Paraplacodus show strong osteosclerosis. Remodelling occurs in the core of the sections and is characterized by abundant endosteal bone deposits so that the medullary area is compacted. The humeri of Placodontia indet. aff. Cyamodus show a strong inhibition of primary bone resorption and remodelling process is initiated although only incompletely. They are similar to those of the diapsid Horaffia kugleri. However, if the latter are characterized by pachyosteosclerosis (Klein and Hagdorn, 2014), those of Placodontia indet. aff. Cyamodus, with no morphologically observable thickening, only display osteosclerosis (S2). As a result of the PCA Placodontia indet. aff. Cyamodus and the diapsid Horaffia kugleri along with Pistosaurus and the pachypleurosaur Anarosaurus are 
well separated from both the remaining placodonts on the one hand and sustained swimmers on the other (Fig. 3).

The Psephoderma femur is characterized by periosteal bone resorption in form of a perimedullary region containing large erosion cavities. This is to a lesser degree also visible in the much smaller and more gracile humerus. Periosteal remodelling is initiated by the deposition of a thin layer of lamellar bone around the large erosion cavities. The femur organization of Psephoderma rather resembles that of the femur, humerus and rib of the diapsid Claudiosaurus (Buffrénil and Mazin, 1989) that was an anguilliform swimmer (Houssaye, 2012). Some humeri and femora from our sample, referred to as Placodontia indet. have a large medullary region consisting of secondary trabecles. The occurrence of open medullary cavities in other femora of Placodontia indet. suggests different functional requirements (swimming styles) and slow swimming skills.

\section{Ecological inferences and possible swimming styles}

According to Ricqlès and Buffrénil (2001), increase in skeletal density and mass is a clear advantage for poorly active aquatic tetrapods because the resulting additional ballast allows a hydrostatic (passive) control of body trim in water and counteracts lung buoyancy. As a result it facilitates diving and extended underwater stays and improves stability in rough water (Taylor, 1994). Conversely, this skeletal specialization increases the inertia of the body and induces limitations of the swimming speed and capabilities to perform rapid maneuvers (Ricqlès and Buffrénil, 2001). A different pattern is a spongeous general organization as a result of the combined absence of medullary cavity with an increase in cortical porosity due to the development of erosion bays, which are not entirely filled up by secondary bone (Ricqlès and Buffrénil, 2001). In general one could say that taxa that lived in shallow water display an increase in bone compactness (Laurin et al., 2004), whereas species that lived in open marine habitats tend to have spongy bone (Ricqlés, 1977), as is obvious in e.g. several ichthyosaurs (Buffrénil and Mazin, 1990; Talevi and Fernandez, 2012; Houssaye et al., 2014).

All placodonts sampled share a thick cortex and clearly display bone mass increase (BMI) via osteosclerosis. However, the processes involved are disparate, as are the same global swimming mode. All placodonts are known from marine sediment except for Henodus that was found in lagoonal or lake sediments.
Thus, based on sediments and microanatomy an aquatic lifestyle in shallow marine habitats can be inferred for all. Due to their specialized durophageous dentition all placodonts have fed predominately on hard shelled mollusks that moved only slowly or were sessile. Thus, there was no need for placodonts to be fast swimmers. However, the discussion of swimming styles and capabilities remains difficult, because among modern aquatic vertebrates only sirenians display BMI, which makes interpretation of the placodont data difficult. Additionally, morphological, histological, and microanatomical inferences contradict each other in some taxa.

BMI is most intense in Paraplacodus. Importantly this taxon lacks any kind of armour, which could otherwise also serve as a source of body mass increase (e.g. Scheyer, 2007). If it was an inefficient swimmer, achieving long dives close to the bottom, a high increase in bone mass would have been advantageous to control buoyancy. BMI is generally concentrated in the anterior portion of the body when it is also involved in body trim control (Houssaye, 2009). The occurrence of strong BMI in Paraplacodus humeri and femora would be in accordance with a bottom-walker rather than shallow-swimmer ecology for this taxon.

Psephoderma alpinum also shows high bone compactness among the sample in spite of resorption processes in the cortex. Psephoderma was armoured with a dorsal shield consisting of a main carapace and a pelvic shield, which increases body mass, too. Its overall habitus and largely inflexible body axis would suggest a comparable swimming style to modern freshwater turtles that is a combination of bottom-walk and rowing with the limbs. However, Psephoderma has slender and short (reduced) limb bones making rowing with effective strokes unlikely. Microanatomy is similar to Claudiosaurus that was an anguilliform swimmer. However, an anguilliform swimming mode for Psephoderma is unlikely due to a largely inflexible body axis (dorsal armour). Although in modern interpretations the dorsal armour is divided at the pelvic region anguilliform movements are still restricted. The best interpretation is so far that Psephoderma has had a passive lifestyle sitting most of the time on the bottom/ground (or was maybe buried in analogy to some flat turtles). For feeding it slowly walked the ground. Certain propulsion by wriggling movements of the pelvic and tail region is conceivable. Higher resorption in the femur than in the humerus further indicates more active movements of the limbs and thus might support more active swimming when compared 
to Paraplacodus (that has a similar high BMI).

Humeri of Placodontia indet. aff. Cyamodus also show BMI although to a lesser extend when compared to Paraplacodus and Psephoderma. The humerus assigned to aff. Placodus, the humerus of Henodus, and the humeri of the diapsid Horaffia all share a similar microanatomy and histology. Thus, similar compactness values are assumed for aff. Placodus and Henodus (although they are both not tested in the PCA due to the lack of a thin section). The lower BMI indicates more efficient swimming in these taxa when compared to Paraplacodus and Psephoderma, because less BMI suggests more maneuverability.

Cyamodus hildegardis was armoured with a dorsal shield consisting of a main carapace and a pelvic shield (Rieppel, 2002; Scheyer, 2010). Other Cyamodus species most likely carried armour as well (as evidenced in C. kuhnschnyderi; see Nosotti and Pinna, 1996) but their exact configuration on the body is not known. In addition, Cyamodus hildegardis also carried a heavily armoured tail (Scheyer, 2010). Henodus was heavily armoured as well, with a closed dorsal and ventral shield (Huene, 1936). Thus, body mass was increased by armour in both taxa. Cyamodus has long and massive humeri, Henodus humeri are tiny (reduced). Based on its morphology, lifestyle and swimming capabilities of Henodus are interpreted as similar to those described above for Psephoderma, making Henodus mainly a bottom walker. No propulsion by wriggling seems possible due to its entirely enclosed body.

Humeri of Placodontia indet. aff. Cyamodus are long and massive (as it is the case in all Cyamodus spp.), allowing strong strokes and making a swimming style by rowing with the limbs possible. [Please note that it is unknown if the feet of any placodont were webbed.] Additionally, the divided dorsal shield would have allowed some (minimal) propulsion by wriggling with the rear and tail.

Placodus has only one single row of osteoderms along its vertebral column that has not much contributed to body mass. It was classified as a subcarangiform swimmer (Braun and Reif, 1985), which is supported by its laterally compressed tail (Drevermann, 1933) and the supposed BMI.

We did not know if armour was present or not for the taxa represented by humeri and femora assigned to Placodontia indet. All bones show a high compactness and have a large spongeous medullary area of a comparable size to that of some otariids (but combined with a much higher compactness in Placodontia indet.). In addition, some femora show an open

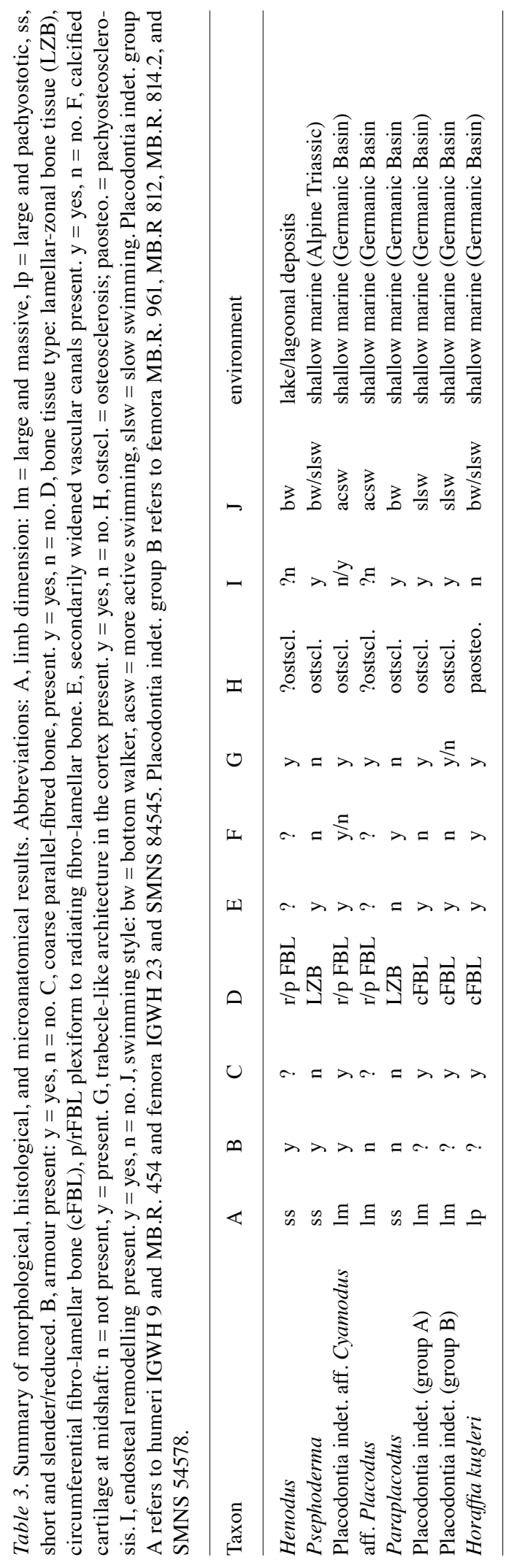


medullary cavity. Thus, microanatomy indicates certain, but not very fast, swimming capabilities.

It is also unknown whether the diapsid Horaffia was armoured. Its humeri were large and pachyostotic (Klein and Hagdorn, 2014). Microanatomy clearly documents osteosclerosis (Klein and Hagdorn, 2014; current study). Both identify this taxon as a shallow marine inhabitant most likely a bottom walker or slow swimmer but due to the lack of a complete skeleton this remains rather speculative.

\section{Histological characteristics}

Placodonts share several histological features. Numerous primary osteons occur in all bones that grew with fibro-lamellar bone. Primary osteons are not developed in Psephoderma alpinum and they are rare in Paraplacodus broilii, which both grew with lamellar-zonal bone. All placodonts share immature (i.e. incompletely lined) primary osteons that predominately occur in the inner cortices. Incompletely lined primary osteons are also described for other Sauropertygia such as a pachypleurosaurs and a pistosauroid (Klein, 2010), and for young Alligator mississippiensis (Woodward et al., 2014). There thus might be a correlation between aquatic lifestyle (and an inferred increased growth rate when compared to terrestrial forms; see White, 2011) and incompletely lined primary osteons.

Resorption occurs in all placodont samples. Psephoderma humerus and femur exhibit a perimedullary region in which periosteal bone is resorbed and partially replaced (remodelled). The entire medullary region of Paraplacodus is made of secondary (endosteal) bone, resulting in a very compact centre. Some Placodontia indet. show an extended medullary region filled by secondary trabecels. In fact, the Placodontia indet. sample can be divided into two groups based on the presence of a medullary cavity in some femora (MB.R. 961; MB.R 812; MB.R 814.2; SMNS 54578) and the presence of a large medullary region, respectively (IGWH 9, 23; SMNS 54585; MB.R. 454). The presence of a free cavity in some Placodontia indet. aff. Cyamodus and Placodontia indet. is not typical for aquatic tetrapods (e.g. Quemeneur et al., 2013; Hayashi et al., 2013).

In those samples that grew with fibro-lamellar bone remodelling is always only initiated, which means that secondarily widened (eroded) vascular canals or primary osteons are surrounded by a layer of circumferentially deposited lamellar bone but stay widely open and are not infilled. Mature secondary osteons are very rare and are restricted to the inner cortex of few samples.
The absence of large amounts of mature secondary osteons (Francillon-Vieillot et al., 1990; Currey, 2002) in the placodont samples expressing fibro-lamellar bone is atypical. Ricqlès (1976) hypothesized a possible relation between fibro-lamellar bone and remodelling (i.e., the presence and number of secondary osteons), which is true for many extant and extinct vertebrates such as large herbivorous mammals, large birds, dinosaurs, and ichthyosaurs (e.g. Klein and Sander, 2008; Houssaye et al., 2014).

All placodonts, thanks to an inhibition of bone remodelling, have a good and fairly complete growth record preserved, which is the subject of another study (Klein et al., unpubl. data).

Paraplacodus, one humerus of Placodontia indet. aff. Cyamodus, and some humeri of Horaffia show pockets of calcified cartilage at midshaft. Retention of calcified cartilage at midshaft is often coupled with osteosclerosis and is recognized in many secondarily aquatic vertebrates, e.g. in pachypleurosaurs and plesiosaurs (Buffrénil et al., 1990; Ricqlès and Buffrénil, 2001; Hugi et al., 2011; Krahl et al., 2013). It is also described in some armour plates of placodonts (Scheyer, 2007).

Two major histological groups can be distinguished among placodonts, which do not follow the classical phylogenetic distinction into armoured vs. non-armoured Placodontia. The armoured Psephoderma and the non-armoured Paraplacodus both grew with compact, low vascularized or avascular lamellar-zonal bone, indicating a slow growth rate and rather low basal metabolic rate comparable to that of modern amphibians and reptiles. The armoured Henodus, non-armoured aff. Placodus, and the armoured Placodontia indet. aff. Cyamodus grew with plexiform to radiating fibro-lamellar bone tissue, indicating high growth rates and a high basal metabolic rate. For Placodontia indet. and for Horaffia it is unknown if the individuals had carried an armour or not, also grew with fibro-lamellar bone tissue but here the organization is more circumferential, indicating somewhat lower growth rates (Margerie et al., 2004). Fibro-lamellar bone tissue is known from modern birds, dinosaurs, most synapsids, and from other extinct marine reptiles such as ichthyosaurs and plesiosaurs (e.g. Chinsamy-Turan 2005, 2011; Houssaye et al., 2014; Wiffen et al., 1995). Thus, fibrolamellar bone tissue clearly originated several times within different vertebrate lineages.

The fibro-lamellar bone of placodonts has the typical scaffolding of woven bone surrounded by lamellar bone. However, sometimes the woven bone component is re- 
placed or grades into parallel-fibred bone with specially thick and coarse fibers. Both always contain a high amount of thick and numerous osteocyte lacunae. A replacement or modification of the woven bone component by parallel-fibred bone in the fibro-lamellar tissue was described before for archosaurs (Ricqlés et al., 2003), the ornithopod dinosaur Gasparinisaura (Cerda and Chinsamy, 2012), and the titanosaur dinosaur Ampelosaurus (Klein et al., 2012). An atypical parallel-fibred bone was mentioned for mosasaurs (Houssaye et al., 2013) and for the temnospondyl Plagiosaurus (Konietzko-Meier and Schmitt, 2013), which both did not grow with fibro-lamellar bone. It also occurs within the fibrolamellar bone of ichthyosaurs (Houssaye et al., 2014).

Locally, a high amount of radial vascular canals occurs within the fibro-lamellar bone of some placodonts. Radial bone tissue reveals according to Margerie et al., (2004:869) in the king penguin chick the highest growth rates. In ichthyosaurs, a radial arrangement of vascular canals was interpreted as a consequence of the insertion of Sharpey's fibers and thus linked to mechanical reasons (Houssaye et al., 2014). The local radial trabecle-like architecture in the inner cortex of some placodont samples may also indicate mechanical properties in addition to high overall growth rates. The fibro-lamellar bone tissue in combination with the plexiform to radiating organization indicates for Placodontia indet. aff. Cyamodus the highest growth rates among placodonts but also among other Triassic Sauropterygia and is comparable to that of ichthyosaurs (Buffrénil and Mazin, 1990; Houssaye et al., 2014).

In all placodonts that grew with fibro-lamellar bone, primary tissue is in general highly vascularized. Locally it is even spongeous-like or trabecular-like. Primary osteons are secondarily widened by successive resorption processes, resulting in an overall secondary spongeous tissue, which is similar to some ichthyosaurs (Houssaye et al., 2014).

In spite of certain inter- and intraspecific variability within the placodont sample that grew with fibro-lamellar bone, the primary bone tissue is in general very similar to that of ichthyosaurs. Differences include the lack of a medullary cavity, high endosteal and periosteal remodelling, and an overall more spongeous organization, in ichthyosaurs (Houssaye et al., 2014). The similarities are notable, because ichthyosaurs were efficient and sustained swimmers that lived in the open marine sea with a comparable body shape and lifestyle to dolphins or tunas. Placodonts have a cylindrical, sea cow-like body shape (non-armoured forms) or resemble the shape and morphology of flat aquatic turtles (armoured forms).
Long bone histology allows the identification and assignment of isolated bone fragments to Placodontia. Neither the combination of the avascular to low vascularized lamellar-zonal bone tissue of Psephoderma and Paraplacodus nor the special plexiform to radiating fibro-lamellar bone tissue of aff. Placodus, Placodontia indet. aff. Cyamodus, and Henodus or circumfertential fibro-lamellar bone of Placodontia indet. has so far been reported in the here described combinations in any long bone of any other marine reptile (e.g. Sander, 1990; Wiffen et al., 1995; Pellegrini 2007; Klein, 2010; Hugi, 2011; Hugi et al., 2011; Krahl et al., 2013; Houssaye et al., 2014).

\section{Different bone tissue types and growth strategies}

As summarized in Table 3, long bone histology indicates two major groups, which do not follow the classical phylogenetic distinction into armoured vs. non-armoured Placodontia (Fig. 1). The armoured Psephoderma and the non-armoured Paraplacodus both grew with lamellar-zonal bone tissue indicating slow growth rates and a low basal metabolic rate, comparable to modern reptiles. Henodus, aff. Placodus, Placodontia indet. aff. Cyamodus, and Placodontia indet. grew with fibro-lamellar bone tissue combined with a high, though extremely variable, vascular density, indicating high growth rates and an increased (sustained high) basal metabolic rate. Both tissue types represent two completely different growth strategies in these closely related taxa. Differences in growth rate and basal metabolic rate as well as the somewhat lower BMI in Henodus, Placodontia indet. aff. Cyamodus, aff. Placodus, and Placodontia indet. could point to a more active lifestyle when compared to Psephoderma and Paraplacodus. Perhaps a more active lifestyle also includes sustained swimming (?migration) over long distances for aff. Placodus, Placodontia indet. aff. Cyamodus, and Placodontia indet. but not for Henodus.

That the two different growth strategies are the result of gross differences in habitat/environment or climate can be excluded. All bones exhibiting fibro-lamellar bone originate from localities within the Germanic Basin, whereas Psephoderma and Paraplacodus samples originate from localities settled in the Alpine Triassic realm. All localities were interpreted to represent shallow marine environments. During the Middle Triassic, climate was subtropical warm with alternating dry and wet seasons (megamonsoonal intervals) (Parrish et al., 1982; Röhl et al., 2001). Accordingly, water temperatures of the Muschelkalk Sea and the Alpine 
Triassic lagoonal settings have been correspondingly high and less metabolic effort was needed for marine reptiles to sustain a high growth- and basal metabolic rate in both realms. Thus, strong differences in paleoclimate can be excluded as explanation why some placodonts grew with fibro-lamellar bone whereas others grew with lamellar-zonal bone.

High predatory pressure that makes faster growth necessary, although conceivable as a trigger for the presence of fibro-lamellar bone in those placodonts from the Germanic Basin, appears very unlikely since predators also occurred in the environments of the Alpine Triassic. Predatory pressure might even be higher in environments of the Alpine Triassic due to the presence of a higher number of possible predators such as ichthyosaurs, large nothosaurs, and thalattosaurs.

So far we can only observe that Henodus, Placodontia indet. aff. Cyamodus, aff. Placodus, and Placodontia indet. followed a different life history strategy when compared to Psephoderma and Paraplacodus the exact reasons for this have yet to be fully understood.

\section{Concluding remarks}

The study of the morphology, long bone microanatomy, and histology of Placodontia clearly shows that extinct taxa are not 'simply similar' to modern taxa but that they could have had a variety of features, which are in certain combinations sometimes without a modern analogy so that the possibilities for interpretation are limited.

Clear evolutionary trends within Placodontia regarding microanatomical and histological features are not observable but identification might be hampered due to still limited sample size. Fibro-lamellar bone tissue already occurs in placodonts from the late early Anisian and persists until the early Carnian with Henodus. The lamellar-zonal bone type is so far only documented in stratigraphically younger placodonts from the Anisian-Ladinian boundary and the Rhaetian. A similar distribution of lamellar-zonal bone and fibrolamellar bone is documented in pachypleurosaurs (Sauropterygia). Neusticosaurus ssp. from the AnisianLadinian boundary of the Alpine Triassic show lamellar-zonal bone (Sander, 1990; Hugi et al., 2011) whereas the stratigraphically older Anarosaurus heterodontus from the Lower Muschelkalk of Winterswijk (Germanic Basin) grow with incipient fibro-lamellar bone (Klein, 2010). This could indicate that the fibro-lamellar bone tissue was inherited from the unknown terrestrial ancestor of Sauropterygia and was later abandoned in some taxa.
In conclusion, all placodonts sampled followed an essentially or probably exclusive aquatic lifestyle. However, we observe distinct differences in histology and microanatomy that lead to different growth strategies and life (swimming) styles in Placodontia independent from phylogenetic relationships, ontogenetic stages or the presence or absence of armour. The differences imply a high inter- as well as intraspecific variability, most likely depending on the environment each individual lived in (developmental plasticity), and diverse lifestyles among the group.

\section{Acknowledgements}

O. Dülfer (StIPB) and Ch. Wimmer-Pfeil (SMNS) are thanked for the production of thin sections. We are grateful to H. Furrer (PIMUZ), H. Hagdorn (MHI), N. Hauschke (IGWH), R. Schoch (SMNS), and D. Schwarz-Wings (MfN) who kindly gave permission for the histological sampling of placodont bones. P. Havlik (GPIT) is acknowledged for the photo of the cross section of the Henodus humerus. M. Sander (StIPB) gave allowance to use the technical equipment at the StIPB and is acknowledged for always inspiring discussions. G. Oleschinski (StIPB) is acknowledged for some of the photographs. D. Konietzko-Meier and Chris Shelton (both StIPB) contributed constructive comments on the thin sections. R. Baumann, A. Kupfer, M. Rasser, and FX. Schmidt (all SMNS) are thanked for technical support. The following persons provided samples for the PCA analyses: H. Furrer (PIMUZ), H. Hagdorn (MHI), N. Hauschke (IGWH), A. Krahl (StIPB), D. Nieweg (TWE), H. Oosterink (Winterswijk), M. Sander (StIPB), R. Schoch (SMNS), and S. Hajashi (OMNH). The study was partly funded by the Swiss National Science Foundation (grant no. 149506 to TMS). AH acknowledges financial support from the ANR-13-PDOC-0011. We are thankful to the constructive comments of I.A. Cerda (Museo de Geologia y Paleontologıa, Universidad Nacional del Comahue, Buenos Aires) and an anonymous reviewer.

\section{References}

Agassiz L. 1833-45. Recherches sur les Poissons Fossiles. - Imprimerie de Petitpierre, Neuchatel.

Bakker RT. 1980. Dinosaur heresy-dinosaur renaissance: why we need endothermic archosaurs for a comprehensive theory of bioenergetic evolution. Pp. 351-362 in: Thomas DK, Olson EC, eds, A cold look at warm-blooded dinosaurs. Washington, D.C.: American Association for the Advancement of Science.

Bell T. 1825. On a new genus of Iguanidae. Zoological Journal 2: 204-208.

Braun J, Reif W-E. 1985. A survey of aquatic locomotion in fishes and tetrapods. Neues Jahrbuch für Geologie und Paläontologie, Abhandlungen 169: 307-312.

Buffetaut E, Novak M. 2008. A cyamodontid placodont (Reptilia: Sauropterygia) from the Triassic of Slovenia. Palaeontology 51: 1301-1306. 
Buffrénil de V, Mazin J-M, Ricqlès de A. 1987. Caractères structuraux et mode de croissance du fémur d'Omphalosaurus nisseri, ichthyosaurien du Trias moyen de Spitsberg. Annales De Paleontologie 73: 195-216.

Buffrénil de V, Mazin J-M. 1989. Bone histology of Claudiosaurus germaini (Reptilia, Claudiosauridae) and the problem of pachyostosis in aquatic tetrapods. Historical Biology 2: 311-322.

Buffrénil de V, Mazin J-M. 1990. Bone histology of the ichthyosaurs: comparative data and functional interpretation. Paleobiology 16: 435-447.

Buffrénil de V, Ricqlès de A, Ray CE, Domning DP. 1990. Bone histology of the ribs of the archaeocetes (Mammalia: Cetacea). Journal of Vertebrate Paleontology 10: 455-466.

Buffrénil de V, Mazin J-M. 1992. Contribution de l'histologie osseuse à l'interpretation paléobiologique du genre Placodus Agassiz, 1833 (Reptilia, Placodontia). Revue Paléobiology 11: 397-407.

Buffrénil de V., Castanet J. 2000. Age estimation by skeletochronology in the Nile monitor lizard (Varanus niloticus), a highly exploited species. Journal of Herpetology 34: 414-424.

Canoville A, Laurin M. 2010. Evolution of humeral microanatomy and lifestyle in amniotes, and some comments on paleobiological inferences. Biological Journal of the Linnean Society 100: 384-406.

Carroll R L. 1988. Vertebrate paleontology and evolution. W.H. Freeman and Company, New York 1-698.

Castanet J, Francillon-Vieillot H, Meunier FJ, Ricqlès de A. 1993. Bone and individual aging. Pp. 245-277 in: Hall BK, ed, Bone Volume 7: Bone Growth-B. Boca Raton, FL: CRC Press.

Chinsamy Turan A. 2005. The microstructure of dinosaur bone. Baltimore: Johns Hopkins University Press.

Chinsamy Turan A. 2011. Forerunners of mammals radiation. Bloomington: Indiana University Press.

Cerda IA, Chinsamy A. 2012. Biological implications of the bone microstructure of the Late Cretaceous Ornithopod Dinosaur Gasparinisaura cincosaltensis. Journal of Vertebrate Paleontology 32: 355-368.

Currey JD. 2002. Bones: structure and mechanics. Princeton: Princeton University Press.

Drevermann FR. 1933. Die Placodontier. 3. Das Skelett von Placodus gigas Agassiz im Senckenberg-Museum. Abhandlungen der senckenbergischen naturforschenden Gesellschaft 38: 319-364.

Dumont M, Laurin M, Jacques F, Pellé E, Dabin W, de Buffrénil V. 2013. Inner architecture of vertebral centra in terrestrial and aquatic mammals: A two dimensional comparative study. Journal of Morphology 274: 570-584.

Erickson GM. 2005. Assessing dinosaur growth patterns: a microscopic revolution. Trends in Ecology and Evolution 20: 677-684.

Ernst HC, Barbour RW. 1989. Turtles of the world. Washington/ London: Smithsonian Institution Press.

Fraas E. 1896. Die Schwäbischen Trias-Saurier nach dem Material der Kgl. Naturalien-Sammlung in Stuttgart zusammengestellt. Festgabe des Königlichen Naturalien-Cabinets in Stuttgart zur 42. Versammlung der Deutschen geologischen Gesellschaft in Stuttgart. E. Schweizerbart'sche Verlagshandlung (E. Koch).
Francillon-Vieillot H, Buffrénil de V, Castanet J, Géradudie J, Meunier FJ, Sire JY, Zylenberg L, Ricqlès de A. 1990. Microstructure and mineralization of vertebrate skeletal tissues. Pp. 471-530 in: Carter JG, ed, Skeletal biomineralization: patterns, processes and evolutionary trends, Volume 1. New York: Van Norstrand Reinhold.

Furrer H, Eichenberger U, Froitzheim N, Wurster D. 1992. Geologie, Stratigraphie und Fossilien der Ducankette und des Landwassergebiets (Silvretta-Decke, Ostalpin). Eclogae geologicae Helvetiae 85: 245-256.

Germain D, Laurin M. 2005. Microanatomy of the radius and lifestyle in amniotes (Vertebrata, Tetrapoda). Zoologica Scripta 34: 335-350.

Girondot M, Laurin M. 2003. Bone profiler: a tool to quantify, model and statistically compare bone section compactness profiles. Journal of Vertebrate Paleontology 23: 458-461.

Griebeler E-M, Klein N, Sander MP. 2013. Aging, maturation and growth of sauropodomorph dinosaurs as deduced from growth curves using long bone histological data. PLoS ONE 8: e67012. doi: 10.1371/journal.pone.0067012.

Hagdorn H, Rieppel O. 1999. Stratigraphy of marine reptiles in the Triassic of Central Europe. Zentralblatt für Geologie und Paläontologie 1998: 651-678.

Hayashi S, Houssaye A, Nakajima Y, Chiba K, Inuzuka N, Sawamura H, Ando T, Osaki T, Kaneko N. 2013. Bone histology suggests increasing aquatic adaptations in Desmostylia (Mammalia, Afrotheria). PLoS ONE 8: e59146. doi: 10.1371/ journal.pone.0059146.

Houssaye A. 2009. 'Pachyostosis' in aquatic amniotes: a review. Integrative Zoology 4: 325-340. doi: 10.1111/j.1749-4877. 2009.00146.x.

Houssaye A. 2012. Bone histology of aquatic reptiles: what does it tell us about secondary adaptation to an aquatic life? Biological Journal of the Linnean Society 108: 3-21.

Houssaye A, Scheyer TM, Kolb C, Fischer V, Sander PM. 2014. A new look at ichthyosaur long bone microanatomy and histology: Implications for their adaptation to an aquatic life. PLOS ONE 9: e95637. doi: 10.1371/journal.pone.0095637.

Houssaye A, Lindgren J, Pellegrini R, Lee AH, Germain D, Polcyn MJ. 2013. Microanatomical and Histological Features in the Long Bones of Mosasaurine Mosasaurs (Reptilia, Squamata) - Implications for Aquatic Adaptation and Growth Rates. PLoS ONE 8: e76741. doi: 10.1371/journal. pone. 0076741

Houssaye A, Mazurier A, Herrel A, Volpato V, Tafforeau P, Boistel R, Buffrénil de V. 2010. Vertebral microanatomy in squamates: structure, growth and ecological correlates. Journal of Anatomy 217: 715-727.

Huene von F. 1936. Henodus chelyops, ein neuer Placodontier. Palaeontographica A 84: 99-148.

Hugi J, Sánchez-Villagra MR. 2012. Histological and skeletochronological analyses on life history and skeletal adaptations in the marine iguana Amblyrhynchus cristatus and in other iguanas. Journal of Herpetology 46: 312-324.

Hugi J, Scheyer TM, Sander PM, Klein N, Sánchez-Villagra MR. 2011. Long bone microstructure gives new insights into the life history data of pachypleurosaurids from the Middle Triassic of Monte San Giorgio, Switzerland/Italy. Comptes Rendus Palevol 10: 413-426.

Jiang D-Y, Motani R, Hao W-C, Rieppel O, Sun Y-L, Schmitz L, Sun Z-Y. 2008. First record of Placodontoidea (Reptilia, 
Sauropterygia, Placodontia) from the Eastern Tethys. Journal of Vertebrate Paleontology 28: 904-908.

Klein N. 2012. Postcranial morphology and growth of the Winterswijk pachypleurosaur Anarosaurus heterodontus (Sauropterygia) from the Lower Muschelkalk of Winterswijk, The Netherlands. Paläontologische Zeitschrift 86: 389-408.

Klein N. 2010. Long Bone Histology of Sauropterygia from the Lower Muschelkalk of the Germanic Basin Provides Unexpected Implications for Phylogeny. PLoS ONE 5: e11613. doi: 10.1371/journal.pone.0011613

Klein N, Sander PM. 2008. Ontogenetic stages in the long bone histology of sauropod dinosaurs. Paleobiology 34: 247-263.

Klein N, Sander PM. 2007. Bone histology and growth of the prosauropod Plateosaurus engelhardti Meyer, 1837 from the Norian bonebeds of Trossingen (Germany) and Frick (Switzerland). Special Papers in Palaeontology 77: 169-206.

Klein N, Scheyer TM. 2014. A new placodont (Placodontia, Sauropterygia) from the Middle Triassic (early Anisian) of the Germanic Basin (Winterswijk, The Netherlands). Acta Palaeontologica Polonica 59: 887-902.

Klein N, Hagdorn H. 2014. Humerus morphology and histology of a new marine reptile (Diapsida) from the MuschelkalkKeuper-Grenzbonebed (Middle Triassic, Ladinian) of Southwest Germany. Paleodiversity 7: 23-38.

Köhler M, Marín-Moratalla N, Jordana X, Aanes R. 2012. Seasonal bone growth and physiology in endotherms shed light on dinosaur physiology. Nature 487: 358-361. doi: 10.1038/ nature11264

Konietzko-Meier D, Klein N. 2013. Unique growth pattern of Metoposaurus diagnosticus krasiejowensis (Amphibia, Temnospondyli) from the Upper Triassic of Krasiejow, Poland. Palaeogeography, Palaeoclimatology, Palaeoecology 370: 145-157.

Konietzko-Meier D, Schmitt A. 2013. A histological study of a femur of Plagiosuchus, a Middle Triassic temnospondyl amphibian from southern Germany, using thin sections and micro-CT scanning. Pp. 97-108 in: Mulder EWA, Jagt JWM, Schulp AS, eds, The Sunday's child of Dutch earth sciences - a tribute to Bert Boekschoten on the occasion of his 80th birthday. Netherlands Journal of Geosciences 92: 97-108.

Krahl A, Klein N, Sander PM. 2013. Evolutionary implications of the divergent long bone histologies of Nothosaurus and Pistosaurus (Sauropterygia, Triassic). BMC Evolutionary Biology 13: 1-23.

Laurin M, Girondot M, Loth M-M. 2004. The evolution of long bone microanatomy and lifestyle in lissamphibians. Paleobiology 30: 589-613.

Laurin M, Meunier FJ, Germain D, Lemoine M. 2007. A microanatomical and histological study of the paired fin skeleton of the Devonian sarcopterygian Eusthenopteron foordi. Journal of Paleontology 81: 143-153.

Laurin M, Canoville A, Germain D. 2011. Bone microanatomy and lifestyle: a descriptive approach. Comptes Rendu Palevol 10: $381-402$.

Li C. 2000. Placodont (Reptilia: Placodontia) from Upper Triassic of Guizhou, Southwest China. Vertebrata PalAsiatica 38: 314-317.

Li C, Rieppel O. 2002. A new cyamodontoid placodont from Triassic of Guizhou, China. Chinese Science Bulletin 47: 156-159.
Mazin J-M, Pinna G. 1993. Paleoecology of the armoured placodonts. Paleontologia Lombarda, n.s. 2: 83-91.

Margerie de E, Robin J-P, Verrier D, Cubo J, Groscolas R, Castanet J. 2004. Assessing a relationship between bone microstructure and growth rate: a fluorescent labelling study in the king penguin chick (Aptenodytes patagonicus). The Journal of Experimental Biology 207: 869-879. doi: 10.1242/ jeb.00841

Meyer von H. 1863. Die Placodonten, eine Familie von Sauriern der Trias. Palaeontographica 11: 175-221.

Montes L, Le Roy N, Perret M, Buffrénil de V, Castanet J, Cubo J. 2007. Relationships between bone growth rate, body mass and resting metabolic rate in growing amniotes: a phylogenetic approach. Biological Journal of the Linnean Society 92: 63-76.

Motani R. 2009. The evolution of marine reptiles. Evolution: Education and Outreach 2: 224-235.

Neenan JM, Scheyer TM. 2012. The braincase and inner ear of Placodus gigas (Sauropterygia: Placodontia) - a new reconstruction based on micro-computed tomographic data. Journal of Vertebrate Paleontology 32: 1350-1357 doi: 10.1080/02724634.2012.695241.

Neenan JM, Klein N, Scheyer TM. 2013. European origin of placodont marine reptiles and the evolution of crushing dentition in Placodontia. Nature Communications 4(1621): 1-7. doi: 10.1038/ncomms2633.

Neenan J, Li C, Rieppel O, Bernardini F, Tuniz C, Muscio G, Scheyer TM. 2014. Unique method of tooth replacement in durophagous placodont marine reptiles, with new data on the dentition of Chinese taxa. Journal of Anatomy 224: 603- 613. doi: 10.1111/joa.12162.

Nosotti S, Pinna G. 1996. Osteology of the skull of Cyamodus kuhnschnyderi Nosotti \& Pinna 1993 (Reptilia, Placodontia). Paleontologia Lombarda, Nuova serie 6: 3-42.

Padian K, Horner JR. 2004. Dinosaur physiology. Pp. 660-671 in: Weishampel DB, Dodson P, Osmólska H, eds, The Dinosauria, 2nd Edition. Berkeley: University of California Press.

Padian K, Horner JR, Ricqlès de A. 2004. Growth in small dinosaurs and pterosaurs: The evolution of archosaurian growth strategies. Journal of Vertebrate Paleontology 24: 555-571.

Parrish JT, Ziegler AM, Scotese CR. 1982. Rainfall patterns and the distribution of coals and evaporites in the Mesozoic and Cenozoic. Palaeogeography, Palaeoclimatology, Palaeoecology 40: 67-101.

Peyer B. 1931. Paraplacodus broilii nov. gen. nov. sp., ein neuer Placodontier aus der Tessiner Trias. Vorlaufige Mitteilung. Centralblatt fur Mineralogie, Geologie und Palaontologie, B 1931: 570-573.

Peyer B. 1935. Die Triasfauna der Tessiner Kalkalpen. VIII. Weitere Placodontierfunde. Abhandlungen der schweizerischen Paläontologischen Gesellschaft 45: 1-26.

Pellegrini A. 2007. Skeletochronology of the limb elements of mosasaurs (Squamata; Mosasauridae). Transactions of the Kansas Academy of Science 110: 83-99.

Quemeneur S, Buffrénil de V, Laurin M. 2013. Microanatomy of the amniote femur and inference of lifestyle in limbed vertebrates. Biological Journal of the Linnean Society 109: 644655. doi: 10.1111/bij.12066

Renesto S, Tintori A. 1995. Functional morphology and mode of life of the Late Triassic placodont Psephoderma alpinum 
Meyer from the Calcare di Zorzino (Lombardy, N Italy). Rivista Italiana di Paleontologia e Stratigrafia 101: 37-48.

Ricqlès de A. 1976. On bone histology of fossil and living reptiles, with comments on its functional and evolutionary significance. Pp. 123-151 in: Bellairs A d'A, Cox B, eds, Morphology and biology of reptiles. London: Academic Press for the Linnean Society of London.

Ricqlès de A. 1977. Recherches paléohistologiques sur les os longs destétrapodes VII - Sur la classification, la signification fonctionnelle et l'histoire des tissus osseux des tétrapodes. Deuxième partie, fin. Annales de Paléontology 63: 133-160.

Ricqlès de A. 1983. Cyclical growth in the long limb bones of a sauropod dinosaur. Acta Palaeontologica Polonica 28: 225232.

Ricqlès de A. 1992. Paleoherpetology now: a point of view. Pp. 1197-1200 in: Adler K, ed., Herpetology: current research on the biology of amphibians and reptiles. Proceedings of the first world herpetological congress. Oxford: Society for the study of amphibians and reptiles.

Ricqlès de A, Buffrénil de V. 2001. Bone histology, heterochronies and the return of tetrapods to life in water: where are we? Pp. 289-310 in: Mazin JM, Buffrénil de V, eds, Secondary Adaptation of Tetrapods to Life in Water. München: Friedrich Pfeil Verlag.

Ricqlès de A, Padian K, Horner JA. 2003. On the bone histology of some Triassic pseudosuchian archosaurs and related taxa. Annales de Paléontologie 89: 67-101.

Rieppel O. 1994. Osteology of Simosaurus gaillardoti, and the phylogenetic interrelationships of stem-group Sauropterygia. Fieldiana (Geology), n.s. 28: 1-85.

Rieppel O. 1995. The genus Placodus: systematics, morphology, paleobiogeography, and paleobiology. Fieldiana (Geology), n.s. 31: $1-44$

Rieppel O. 2000a. Sauropterygia I. Pp 1-134 in: Wellnhofer P, ed, Encyclopedia of Paleoherpetology, Volume 12A. München: Friedrich Pfeil Verlag.

Rieppel O. 2000b. Paraplacodus and the phylogeny of the Placodontia (Reptilia: Sauropterygia). Zoological Journal of the Linnean Society 130: 635-659.

Rieppel O. 2001. The cranial anatomy of Placochelys placodonta Jaeckel, 1902, and a review of the Cyamodontoidea (Reptilia, Placodonta [sic]). Fieldiana (Geology), n.s. 45: 1-104.

Rieppel O. 2002. The dermal armour of the cyamodontoid placodonts (Reptilia, Sauropterygia): morphology and systematic value. Fieldiana (Geology), n.s. 46: 1-41.

Rieppel O, Hagdorn H. 1997. Paleobiogeography of Middle Triassic Sauropterygia in central and western Europe. Pp. 121144 in: Callaway JM, Nicholls EL, eds, Ancient Marine Reptiles. San Diego, California: Academic Press.

Röhl H-J, Schmid-Röhl A, Furrer H, Frimmel A, Oschmann W, Schwark L. 2001. Microfacies, geochemistry and palaeoecology of the Middle Triassic Grenzbitumenzone from Monte San Giorgio (Canton Ticino, Switzerland). Geologia Insubrica 6: 1-13.

Sander PM. 1990. Skeletochronology in the small Triassic reptile Neusticosaurus. Annales des Sciences Naturelles, Zoologie (13)11: 213-217.

Sander PM, Klein N. 2005. Developmental plasticity in the life history of a prosauropod dinosaur. Science 310: 1800-1802.

Sander PM, Klein N, Albers PCH, Bickelmann C, Winkelhorst H. 2013. A skeleton of a basal Pistosauroidea from the Lower
Muschelkalk of the Germanic Basin (Winterswijk, The Netherlands) and a reworked and extended phylogenetic analysis of Triassic Sauropterygia. Paläontologische Zeitschrift 88: 55-71. doi: 10.1007/s12542-013-0181-5

Sanchez S, Schoch RR, Ricqlès de A, Steyer JS. 2010. Palaeoecological and palaeoenvironmental influences revealed by long-bone palaeohistology: the example of the Permian branchiosaurid Apateon. Pp. 137-147 in: Vecoli M, Clément G, Meyer Berthaud B, eds, The terrestrialization process: modelling complex interactions at the biosphere geosphere Interface. London: The Geological Society.

Scheyer TM. 2007. Skeletal histology of the dermal armour of Placodontia: the occurrence of 'postcranial fibro-cartilaginous bone' and its developmental implications. Journal of Anatomy 211: 737-753. doi: 10.1111/j.1469-7580.2007.00815.x

Scheyer TM. 2010. New interpretation of the postcranial skeleton and overall body shape of the placodont Cyamodus hildegardis Peyer, 1931 (Reptilia, Sauropterygia). Palaeontologia Electronica 13: 15A: 15p.

Scheyer TM, Neenan JM, Renesto S, Saller F, Hagdorn H, Furrer H, Rieppel O, Tintori A. 2012. Revised paleoecology of placodonts - with a comment on 'The shallow marine placodont Cyamodus of the central European Germanic Basin: its evolution, paleobiogeography and paleoecology' by C.G. Diedrich (Historical Biology, iFirst article, 2011, 1-19, doi: 10.1080/08912963.2011.575938). Historical Biology 24: 257-267.

Talevi M, Fernández MS. 2012. Unexpected skeletal histology of an ichthyosaur from the Middle Jurassic of Patagonia: implications for evolution of bone microstructure among secondary aquatic tetrapods. Naturwissenschaften 99: 241244.

Taylor MA. 2000. Functional significance of bone ballast in the evolution of buoyancy control strategies by aquatic tetrapods. Historical Biology 14: 15-31.

Vogt CH. 1983. Evolutive Palökologie der Placodontier (Placodus, Henodus; Euryapsida, Trias). Ph.D.Thesis, EberhardKarlsUniversity, Tübingen.

Westphal F. 1988. Pflasterzahnsaurier (Placodonten) aus dem süddeutschen Muschelkalk (Mitteltrias). Pp. 151-165 in: Hagdorn H, ed, Neue Forschungen zur Erdgeschichte von Crailsheim. Stuttgart: Goldschneck, Korb.

Wiffen J, Buffrénil de V, Ricqlès de A, Mazin J-M. 1995. Ontogenetic evolution of bone structure in Late Cretaceous Plesiosauria from New Zealand. Geobios 28: 625-640.

White CR, 2011. Allometric estimation of metabolic rates in animals. Comparative Biochemistry and Physiology, Part A: 346-357.

Woodward H, Horner JO, Farlow JO. 2014. Quantification of intraskeletal histovariability in Alligator mississippiensis and implications for vertebrate osteohistology. PeerJ 2: e422. doi: $10.7717 /$ peerj.422.

Zhao L-J, Li C, Liu J, He T. 2008. A new armoured placodont from the Middle Triassic of Yunnan Province, southwestern China. Vertebrata PalAsiatica 46: 171-177.

Received: 16 July 2014

Revised and accepted: 18 November 2014

Published online: 23 February 2015

Editor: M. Brazeau 


\section{Online supplementary material}

S1. Morphological description of sampled humeri and femora

S2. Photographs of sampled bones.

S3. Table with Bone Profiler values.

S4. Cross sections of bones transformed into black and white pictures.

S5. Histological details of Placodontia.

S6. Histological details of Placodontia. 


\section{S1. Morphological description of sampled humeri and femora}

The classical bone bed localities from the Germanic Basin have largely produced isolated bones. As a result, alpha taxonomy of Sauropterygia is often essentially based on skull morphology and taxa are only incompletely known (Rieppel, 2000). Postcranial morphology of Triassic Sauropterygia is highly conservative and uniform. As a consequence taxonomical assignment of isolated bones is generally difficult. Previous studies suggested that, in sauropterygians, bone histological features can be used to support taxonomical assignment (e.g., Klein, 2010, 2012; Sander et al., 2013). Bones of placodonts are rarer than those of eosauropterygians such as Nothosauria and Pachypleurosauria. Additionally, isolated bones are often incompletely preserved or highly weathered, making taxonomic assignment still more problematic. The here described humeri and femora are assigned to Placodontia because their morphology (summarized in Rieppel, 2000) and histology (Buffrénil and Mazin, 1992; Klein, 2010) differs from that of Eosauropertygia (e.g., Sander, 1990; Klein, 2010; Hugi, 2011; Hugi et al., 2011; Krahl et al., 2013). Placodont humeri are more massive and have a simpler morphology with less features than eosauropterygian ones. This means that they are more adapted to an aquatic lifestyle when compared to Eosauropterygia humeri. Femora are more curved (heads twisted), and display distinct condyli with a well-developed fourth trochanter. However, proximal and midshaft fragments of placodont humeri and femora are often hard to taxonomically identify. The assignment of the sampled bones is - if not mentioned otherwise - based on morphological features. The here described bones were compared in detail to published material (see references below). Their assignment is however, often only tentatively due to the lack of diagnostic and/or comparable material.

Both the humerus and femur of Psephoderma experienced distal taphonomic compaction. The humerus of Psephoderma PIMUZ A/III 1476 is long and slender with a laterally expanded and curved rectangular proximal head (S2C, D). The distinctly constricted narrow/slender midshaft has a postaxially curved and preaxially straight margin. The distal end is broad and flattened, the natural condition being undoubtedly amplified by the taphonomic compaction. The femur PIMUZ A/III 0735 is proximally incomplete and has a similar shape to the humerus except for a straight midshaft region and a less expanded proximal head. Both cross sections are round-oval with a slightly pointed preaxial side. For further morphological details and a comparison of the here included bones see Meyer (1858), Pinna and Nossotti (1989), and Renesto and Tintori (1995).

The humerus of Henodus belongs to one (GPIT/RE/7289) of the seven known specimens (Huene, 1936, 1938). The humerus is preaxially straight and postaxially concave with a constricted midshaft. The massive proximal head is thick and round to oval. The broad and flat distal end is twisted. The humerus is bent in a ventral direction and dorsoventrally flattened (S2E). The cross section is oval with a slightly convex dorsal margin and a straight ventral margin. Both lateral margins are convex with the preaxial side pointed. For further morphological details see Huene, 1936, 1938).

In the Muschelkalk, no Cyamodus skull has yet been found together with a humerus. Isolated humeri can thus only tentatively be assigned to Cyamodus (Vogt, 1983; Rieppel, 1995; Klein and Hagdorn, in press). Several humeri that share certain morphological and histological features where combined as Placodontia indet. aff. Cyamodus. However, this assignment is only tentatively and the group might include different taxa as is indicated by the study of the growth record (Klein et al., unpubl. data). Humeri of Placodontia indet. aff. Cyamodus are morphologically variable (S2F-M), which could be the result of inter-specific variation, intraspecific variation or ontoegentic variation. They have a thick proximal head, a curved and slender midshaft, and a fan-shaped, flat distal end. The proximal head has a triangular shape with the dorsopreaxial margin forming the peak of the isolescent triangle. The proximal head is twisted ventrally in relation to the midshaft. The most distinct and unique character of humeri of Placodontia indet. aff. Cyamodus is a concavity at the ventropostaxial side of the proximal head (Klein and Hagdorn, in press). The distal end has an ectepicondylar groove, a capitellum and an entepicondyle. SMNS 59831 is a large, fan-shaped, and flat distal end of a humerus with a deep ectepicondylar groove and an entepicondyle. The preserved midshaft is constricted with 
straight margins (S2F). SMNS 15937 is a complete dorso-ventrally flattened humerus with poorly preserved proximal and distal ends. The flat proximal head is shorter than the half-round and flat distal end. The proximal head is ventro-preaxially flat/straight rather than concave (S2J). MHI 2112-6 is a large, slender, and slightly curved humerus. The broad proximal head is ventro-postaxially slightly concave. The shaft is slender and constricted. The distal end is broad and flat but due to preparation morphological details are obscured (S2G). Humerus SMNS 54569 has at the broad proximal head the characteristic concavity at the ventropostaxial side. Although the distal end of SMNS 54569 is missing the curvature of the slender shaft is obvious (S2I). SMNS 15891 is only poorly preserved and confidently establish its morphology is not possible. The humerus SMNS 15891 has a dorso-ventrally flattened shape; the midshaft is slightly curved, and it has a symmetrical broadened half-round distal end (S2H). The distal humerus fragment MHI 697 is only poorly preserved, consisting of a constricted, slender and curved shaft. The distal end is flattened; fan shaped, and has an ectepicondylar groove (S2L). SMNS 54582 is the distal half of a humerus. The shaft is constricted and postaxially slightly curved. The distal end is fan-shaped with striations on the ventral and dorsal sides. An ectepicondylar groove is developed. The entire bone is dorsoventrally very flat (S2K). MHI 1096 is the proximal half of a humerus with a slightly curved midshaft. The broad proximal head is incomplete, poorly preserved, and the characteristic proximal concavity described for Placodontia indet. aff. Cyamodus (Klein and Hagdorn, in press) is not visible. The postaxial half is flat rather than concave (S2M). MHI 1096 is similar to the much larger humerus fragment SMNS 54569. The overall shape of the midshaft cross sections is oval with a slightly convex dorsal margin and a straight ventral margin that becomes postaxially convex. Both lateral margins are convex and the preaxial side is pointed. In SMNS 54582 and MHI 697 the cross section is dorsoventrally flattened, whereas that of MHI 1096 is rounder, when compared to the others.

In the Muschelkalk, so far no Placodus skull has been found together with a humerus. The humerus associated with the nearly complete Placodus skeleton described by Drevermann (1933) belongs to a nothosaur (Rieppel 1995). Isolated humeri can thus only tentatively be assigned to Placodus (Vogt, 1983; Rieppel, 1995; Klein and Hagdorn, in press). Femur morphology of Placodus was described by Drevermann (1933) and Rieppel (1995).

It has a slender and straight midshaft region. The proximal head is characterized by a well-developed trochanter. Humeri assigned to aff. Placodus possess a rectangular shaped proximal head, which means that no proximal margin is protruding. The postaxial side is covered with striations. The proximal head is not twisted in relation to shaft or distal end, resulting in a general dorsoventrally flattened shape. The midshaft is constricted, postaxially curved but preaxially nearly straight. The symmetrical broadened distal end of aff. Placodus humerus is divided into an entepicondyle, an ectepicondylar groove, and an ectepicondyle (Rieppel, 1994). In humerus SMNS 59827 a partially broken off entepicondylar foramen is also identified (S2O). The shape of the midshaft cross section resembles that of humeri of Placodontia indet. aff. Cyamodus.

Humerus PIMUZ T 5845 and femur PIMUZ T 5845 are assigned to Paraplacodus based on their morphology (see Peyer, 1935, Rieppel, 2000a, b). Both bones are distally extremely flattened as a result of taphonomic processes. The midshaft region underwent very slight compaction in the humerus and little to no compaction in its proximal part. The humerus also experienced proximally some surface erosion. The humerus of Paraplacodus (PIMUZ T 5845) has a postaxially concave and preaxially straight margin. The proximal head is rectangular with a straight postaxial surface and a well set off margin (S2A, B) and not distinctly broadened. The constricted midshaft leads to a broad and flat distal end. The femur of Paraplacodus (PIMUZ T 5845) has a thick and massive proximal end, a slender constricted shaft. The broad proximal articular surface carries at the postaxial portion a distinct concave indentation. Postaxially, the bone is shorter and more curved than the preaxial side. It has an oval midshaft cross section. The flat distal end is less broad than the proximal head and the roughly equally sized condyli are not easy to distinguish. The femur is dorsoventrally curved. Due to bone ratio and find situation both bones can well belong to the same individual. For further morphological details on humerus and femur morphology of Paraplacodus see Peyer (1935) and Rieppel (2000). The humerus (PIMUZ T5845) cross section is elliptical with a convex dorsal, a concave 
ventral side and a preaxially more pointed side than postaxially (S4A). The femur (PIMUZ T 5845) cross section is round-oval (S4B).

The following humeri and femora have placodont affinities due to their morphology and histology but did not match any described taxon and are thus assigned to Placodontia indet. Due to morphological, histological and microanatomical diferecnes these bones represent more than one taxon (see also Klein et al., unpubl. data). Humerus MB.R. 454 (S2P) and IGWH 9 (S2Q) share a distinct midshaft cross section with a slightly convex dorsal margin and a divided ventral margin. The preaxial half of the ventral margin is straight but the postaxial half convex. Both lateral margins are convex with a pointed preaxial side. IGWH-9 is a complete left humerus, which was already figured and described in Klein (2010). It has a simple morphology with a roughly crescent-shaped form. Although poorly preserved, the proximal head seems to have been originally rectangular. The incomplete distal end is broad and flat and carries an ectepicondylar groove. The shaft is only minimally constricted. The postaxial margin is curved the preaxial one straight and the entire humerus dorsoventrally flattened. The midshaft cross section has a convex dorsal margin, preaxially the ventral margin is straight, but it becomes postaxially convex. Both lateral margins are convex with a pointed preaxial side. Humerus MB.R. 454 has a simple rectangular proximal head, a postaxial striation pattern, a postaxially curved midshaft, and a dorso-ventrally flattened general shape. The distal end is not symmetrical broadened which, however, can be obscured due to preservation and preparation artifacts.

Femora SMNS 84545 (S2R) and IGWH 23 (S2S) share an obconical shaped cross section. The ventral margin is long and slightly convex; the dorsal margin is shorter and straight (minimal convex in IGWH 23). The lateral margins of SMNS 84545 are both in their dorsal portion concave but in the ventral half convex that of IGWH 23 are both convex. IGWH 23 is the incomplete proximal end of a right femur, which was already figured and described in Klein (2010). The proximal head is rectangular; the shaft is straight. The midshaft cross section has a rather untypical form. The ventral margin is long and concave; the dorsal one short and convex. Both lateral margins are convex. SMNS 54578 is only incompletely preserved and the morphology of the proximal and distal ends cannot be established. The bone represents a femur, because the proximal head is longer than wide (Table 1), the midshaft cross section is round-oval, and the midshaft has straight margins. SMNS 84545 is a ?proximally poorly preserved and ?distally incomplete femur. The midshaft area however, is well preserved and exhibits a very special cross section, comparable to that of IGWH 23.

Femora MB. R. 814.2 (S2T), MB.R. 961 (S2U), SMNS 54578 (S2V), MB.R. 812 (S2W) share a round oval cross section. MB.R. 814.2 is a poorly preserved and broken, hollow/cavernous midshaft. Femora MB.R. 961 and MB.R. 812 both have only incompletely preserved proximal and distal ends and the morphology cannot be established. Due to their size, their straight and round midshaft regions taxonomical affinities to pachypleurosaur or nothosaur can be excluded (but not those to pistosaurs). Their assignment to Placodontia and their identification as femora is solely based on the shape of their cross sections and their bone histology (see below). The cross section of femur MB.R. 965 (S2X) is largely round but with a distinct peak preaxially, indicating the position of the $4^{\text {th }}$ trochanter.

The taxon Horaffia kugleri is only based on five humeri, most likely representing a growth series (Klein and Hagdorn, in press). Humeri of $H$. kugleri are pachyostotic and have a dorsopreaxially elongated margin, a massive and ventrally protruding triangular proximal head as well as a preaxially slanted asymmetrical distal end. They are easy to distinguish from Cyamodus, Placodontia indet. aff. Cyamodus, aff Placodus and Placodus humeri and all other here described long bones (S2N) However, although their phylogenetic relationship and possible placodont affinities remain unresolved their bone histology and microanatomy largely resembles those of aff. Cyamodus (Klein and Hagdorn, in press), which is the reason why Horaffia is included into the current study. 


\section{References}

Buffrénil de V, Mazin J-M. 1992. Contribution de l'histologie osseuse à l'interpretation paléobiologique du genre Placodus Agassiz, 1833 (Reptilia, Placodontia). Revue Paléobiology 11: 397-407.

Drevermann FR. 1933. Die Placodontier. 3. Das Skelett von Placodus gigas Agassiz im SenckenbergMuseum. Abhandlungen der Senckenbergischen Naturforschenden Gesellschaft 38: 319-364.

Huene v F. 1936. Henodus chelyops, ein neuer Placodontier. Palaeontographica A 84: 99-148.

Huene v F. 1938. Der dritte Henodus, Ergänzungen zur Kenntnis des Placodontiers Henodus chelyops Huene. Palaeontographica A 89: 105-114.

Hugi J, Scheyer TM, Sander PM, Klein N, Sánchez-Villagra MR. 2011. Long bone microstructure gives new insights into the life history data of pachypleurosaurids from the Middle Triassic of Monte San Giorgio, Switzerland/Italy. Comptes Rendus Palevol 10: 413-426.

Hugi J. 2011. The long bone histology of Ceresiosaurus (Sauropterygia, Reptilia) in comparison to other eosauropterygians from the Middle Triassic of Monte San Giorgio (Switzerland/Italy). Swiss Journal of Palaeontology 130(2): 297-306.

Klein N. 2010. Long Bone Histology of Sauropterygia from the Lower Muschelkalk of the Germanic Basin Provides Unexpected Implications for Phylogeny. PLoSOne 5(7): e11613. doi:10.1371/journal.pone.0011613.

Klein N. 2012. Postcranial morphology and growth of the Winterswijk pachypleurosaur Anarosaurus heterodontus (Sauropterygia) from the Lower Muschelkalk of Winterswijk, The Netherlands. Paläontologsiche Zeitschrift 86(4): 389-408.

Klein N, Hagdorn H. in press. Humerus morphology and histology of a new marine reptile (Diapsida) from the Muschelkalk-Keuper-Grenzbonebed (Middle Triassic, Ladinian) of Southwest Germany. Paleodiversity. X: X-X.

Krahl A, Klein N, Sander PM. 2013. Evolutionary implications of the divergent long bone histologies of Nothosaurus and Pistosaurus (Sauropterygia, Triassic). BMC Evolutionary Biology, 13: 1-23.

Meyer v H. 1858. Psephoderma Alpinum aus dem Dachsteinkalke der Alpen. Neues Jahrbuch für Mineralogie, Geognosie, Geologie und Petrefaktenkunde 1858: 646-650.

Peyer, B. (1935). Die Triasfauna der Tessiner Kalkalpen. VIII. Weitere Placodontierfunde. Abhandlungen der schweizerischen Palaontologischen Gesellschaft 55: 1-26.

Renesto S, Tintori A. 1995. Functional morphology and mode of life of the Late Triassic placodont Psephoderma alpinum Meyer from the Calcare di Zorzino (Lombardy, N Italy). Rivista Italiana di Paleontologia e Stratigrafia 101: 37-48.

Rieppel O. 1994. Osteology of Simosaurus gaillardoti, and the phylogenetic interrelationships of stem-group Sauropterygia. Fieldiana Geology, n. s. 28: 1-85.

Rieppel O. 1995. The genus Placodus: Systematics, morphology, paleobiogeography, and paleobiology. Fieldiana (Geology), n.s. 31: 1-44.

Rieppel O. 2000a. Sauropterygia I. Pp 1-134 in: Wellnhofer P, ed., Encyclopedia of Paleoherpetology, Volume 12A. München: Friedrich Pfeil Verlag.

Rieppel O. 2000b. Paraplacodus and the phylogeny of the Placodontia (Reptilia: Sauropterygia). Zoological Journal of the Linnean Society, London 130: 635-659.

Sander PM. 1990. Skeletochronology in the small Triassic reptile Neusticosaurus. Annales des Sciences Naturelles, Zoologie (13)11: 213-217.

Sander PM, Klein N, Albers PCH, Bickelmann C, Winkelhorst H. 2013. A skeleton of a basal Pistosauroidea from the Lower Muschelkalk of the Germanic Basin (Winterswijk, The Netherlands) and a reworked and extended phylogenetic analysis of Triassic Sauropterygia. Paläontologische Zeitschrift 88: 55-71.

Vogt C. 1983. Evolutive Palökologie der Placodontier (Placodus, Henodus; Euryapsida, Trias). PhD

Dissertation, Eberhard-Karls-Universität, Tübingen, Germany. p. 1-99. 


\section{S2. Photographs of sampled bones}
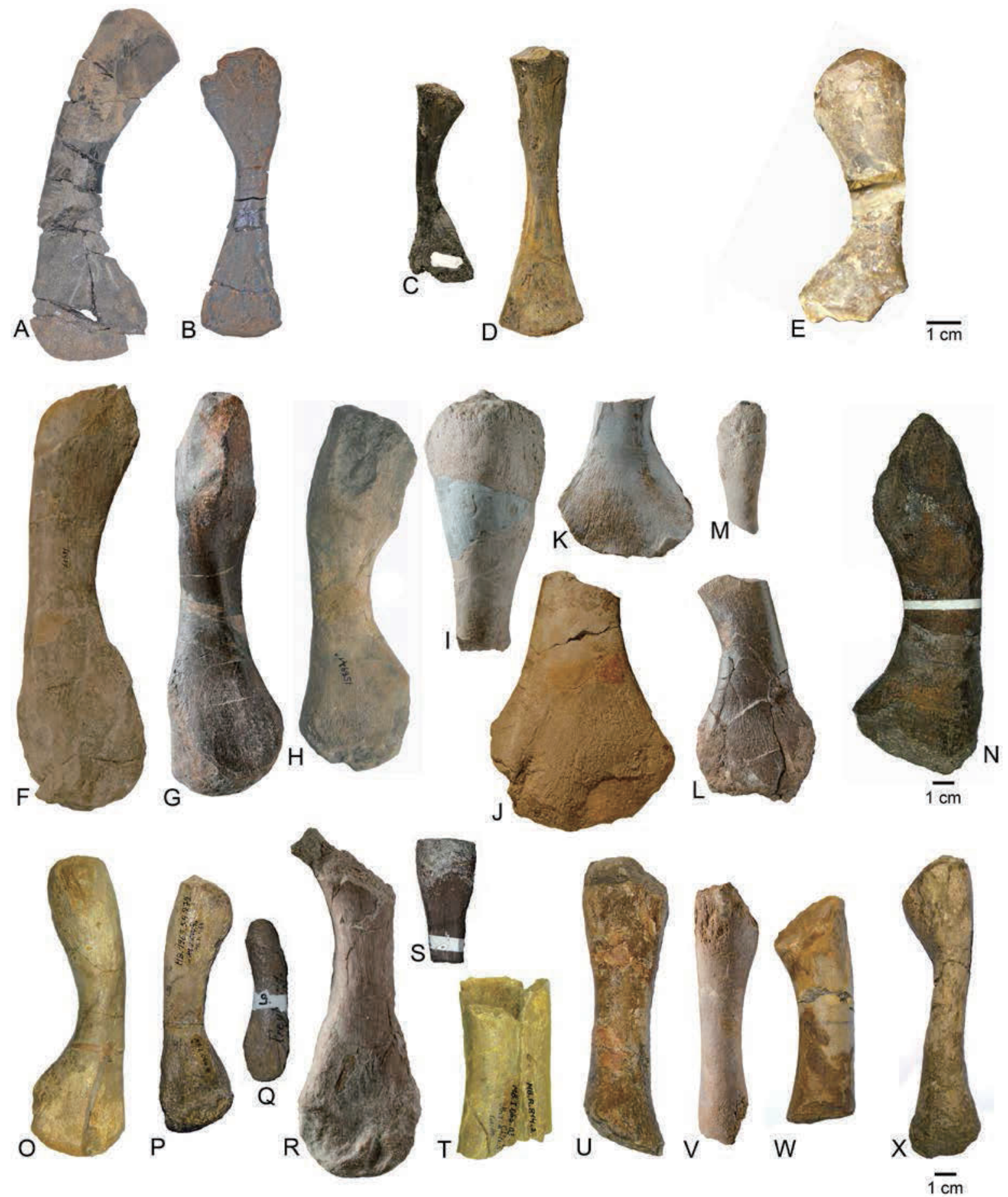

A, Humerus and B, Femur of Paraplacodus broilli (PIMUZ T5845) from the Anisian/Ladinian (Besano Formation, Grenzbitumenhorizont) of the locality of Monte San Giorgio (Switzerland/Italy). C, Humerus (PIMUZ A/III 1476) and D, Femur (PIMUZ A/III 0735) of Psephoderma alpinum from the Rhaetian (Kössener Formation) of Tinzenhorn (Switzerland). E, Humerus of Henodus cheylops (GPIT spec. no. 1) from the Carnian of Tübingen-Lustnau (Baden Württemberg, Germany). F-M, Humeri of Placodontia indet. aff. Cyamodus. from the early Ladinian (Upper Muschelkalk) of southern Germany (see Table 1 for locality information). F, SMNS 15937. G, Humerus MHI 2112/6. H, Humerus SMNS 15891. I, proximal part of humerus SMNS 54569. J, distal part of humerus SMNS 59831. K, distal part of humerus SMNS 54582. L, 
distal part of humerus MHI 697. M, proximal part of humerus MHI 1096. N, Humerus MHI 2112-4 of the marine reptile Horaffia kugleri from the middle Ladinian (Upper Muschelkalk/Keuper Grenzbonebed) of Obersontheim-Ummenhofen (Crailsheim, Baden Württemberg, Germany). O, Humerus (SMNS 59827) assigned to Placodus gigas (Vogt, 1983; Rieppel, 1995) from the early Ladinian (Upper Muschelkalk) of Hegnabrunn (Franconia, Bavaria, Germany). P-X Humeri and femora of Placodontia indet. P, Placodont humerus MB.R. 454 from the early Anisian (Lower Muschelkalk) of Ohrdruf (Górny Śląsk, Poland). Q, Placodont humerus IGWH 9 from the Anisian (Lower/Middle Muschelkalk) of Freyburg (Unstrut river valley, East-Germany). R, Proximal part of a placodont femur SMNS 84545 from the middle Ladinian (Upper Muschelkalk/Keuper) of Hegnabrunn (Franconia, Bavaria, Germany). S, Placodont femur IGWH 23 from the Anisian (Lower/Middle Muschelkalk) of Freyburg (Unstrut river valley, East-Germany). T, Midshaft region of placodont femur MB.R. 814.2 from the early Anisian (Lower Muschelkalk) of Górny Śląsk (Poland). U, Midshaft region of placodont femur MB.R. Ladinian (UpperMuschelkalk) of Bayreuth (Germany), Midshaft region of placodont femur SMNS 54578 from the early Ladinian (Upper Muschelkalk) of Hegnabrunn (Franconia, Bavaria). W, Midshaft region of placodont femur MB.R. 812 from the early Anisian (Lower Muschelkalk) of Opatowitz (Górny Śląsk, Poland). X, Femur MB.R. 965 from the early Anisian (Lower Muschelkalk) of Górny Śląsk (Poland). 


\section{S3. Bone profiler values of the analysed humeri and femora}

$\mathrm{C}$ is the global bone compactness for the whole sectional area. $\mathrm{P}$ is the relative distance from the centre of the section to the point of inflection, where the most abrupt change in compactness is observed. $\mathrm{P}$ is thus proportional to the size of the medullary cavity. $\mathrm{S}$ is the reciprocal of the slope at the inflection point and generally reflects the width of the transition zone between the cortical bone and the medullary region.

\begin{tabular}{|c|c|c|c|c|c|c|}
\hline Humerus & abbr. & $\mathbf{C}$ & $\mathbf{S}$ & $\mathbf{P}$ & Min & Max \\
\hline Placodontia & Fig. 8 & & & & & \\
\hline $\begin{array}{l}\text { Psephoderma alpinum } \\
\text { PIMUZA/III } 1476\end{array}$ & Ps & 91.2 & 0.2522054 & 0.100823 & 0.3284395 & 0.9974383 \\
\hline $\begin{array}{l}\text { Placodontia indet. } \\
\text { aff. Cyamodus } \\
\text { SMNS } 59831\end{array}$ & - & 82.3 & 0.0192668 & 0.0516515 & 0.0000011 & 0.8267046 \\
\hline $\begin{array}{l}\text { Placodontia indet. } \\
\text { aff. Cyamodus } \\
\text { SMNS } 15937\end{array}$ & - & 79.9 & 0.0588768 & 0.080027 & $1.00 \mathrm{E}+00$ & 0.8125375 \\
\hline $\begin{array}{l}\text { Placodontia indet. } \\
\text { aff. Cyamodus } \\
\text { MHI 2112-6 (part) }\end{array}$ & - & 84.7 & 0.0149849 & 0.0350636 & 0.000000967 & 0.8487779 \\
\hline $\begin{array}{l}\text { Placodontia indet. } \\
\text { aff. Cyamodus } \\
\text { SMNS } 54569\end{array}$ & - & 87.1 & 0.0147433 & 0.0549787 & 0.685 & 0.874075 \\
\hline $\begin{array}{l}\text { Placodontia indet. } \\
\text { aff. Cyamodus } \\
\text { SMNS } 54582\end{array}$ & - & 84.7 & 0.0232605 & 0.155462 & 0.154 & 0.87024 \\
\hline $\begin{array}{l}\text { Placodontia indet. } \\
\text { aff. Cyamodus } \\
\text { MHI } 697\end{array}$ & - & 81.8 & 0.0130419 & 0.1688655 & 0.000000148 & 0.8424392 \\
\hline $\begin{array}{l}\text { Placodontia indet. } \\
\text { aff. Cyamodus } \\
\text { SMNS } 15891\end{array}$ & - & 85.9 & 0.0077368 & 0.0881896 & 0.000000244 & 0.8661181 \\
\hline $\begin{array}{l}\text { Placodontia indet. } \\
\text { aff. Cyamodus } \\
\text { MHI } 1096\end{array}$ & - & 78.5 & 0.0111719 & 0.1417196 & 0.000000433 & 0.8014756 \\
\hline $\begin{array}{l}\text { Paraplacodus broilii } \\
\text { PIMUZ T } 5845\end{array}$ & $\mathrm{~Pa}$ & 94.7 & 0.0971625 & 0.000001 & 0.3456165 & 0.9467067 \\
\hline $\begin{array}{l}\text { Placodontia indet. } \\
\text { MB.R. } 454\end{array}$ & $\mathrm{P}$ & 82.4 & 0.0796261 & 0.4757301 & 0.4843481 & 0.9367116 \\
\hline $\begin{array}{l}\text { Placodontia indet. } \\
\text { IGWH } 9\end{array}$ & $\mathrm{P}$ & 82.7 & 0.2593411 & 0.0695503 & 0.000000897 & 0.9402868 \\
\hline \multicolumn{7}{|l|}{ Pachypleurosauria } \\
\hline $\begin{array}{l}\text { Anarosaurus heterodontus } \\
\text { TWE } 48000023\end{array}$ & - & 82.5 & 0.0369192 & 0.3300958 & 0.000000775 & 0.9329377 \\
\hline $\begin{array}{l}\text { Anarosaurus heterodontus } \\
\text { Wijk08-183 }\end{array}$ & - & 78.8 & 0.054676 & 0.2635428 & 0.000000341 & 0.8574109 \\
\hline $\begin{array}{l}\text { Neusticosaurus sp. } \\
\text { PIMUZ T 3455-2 }\end{array}$ & $\mathrm{Ne}$ & 92 & 0.051431 & 0.000001 & 0.00000261 & 0.9237458 \\
\hline
\end{tabular}




\begin{tabular}{|c|c|c|c|c|c|c|}
\hline Nothosauria & & & & & & \\
\hline $\begin{array}{l}\text { Nothosaurus sp. } \\
\text { SMNS } 84772\end{array}$ & - & 76.2 & 0.3090958 & 0.2595539 & 0.00000197 & 0.999999 \\
\hline $\begin{array}{l}\text { Nothosaurus ?giganteus } \\
\text { MB.R. } 269\end{array}$ & - & 51.4 & 0.0665729 & 0.8226691 & 0.293 & 0.999999 \\
\hline $\begin{array}{l}\text { Nothosaurus sp. } \\
\text { MHI } 754\end{array}$ & - & 70.9 & 0.1215368 & 0.4458386 & 0.0000000876 & 0.940332 \\
\hline $\begin{array}{l}\text { Simosaurus gaillardoti } \\
\text { SMNS } 18698\end{array}$ & - & 81.7 & 0.175219 & 0.0483883 & 0.000000754 & 0.8711621 \\
\hline $\begin{array}{l}\text { Simosaurus gaillardoti } \\
\text { SMNS } 52095\end{array}$ & - & 75.9 & 0.1203213 & 0.3304208 & 0.0418088 & 0.8910345 \\
\hline \multicolumn{7}{|l|}{ Pistosauria } \\
\hline $\begin{array}{l}\text { Cymatosaurus sp. } \\
\text { IGWH } 19\end{array}$ & - & 91.8 & 0.2037634 & 0.0689963 & 0.909758 & 0.999999 \\
\hline $\begin{array}{l}\text { Cymatosaurus sp. } \\
\text { Wijk11-39 }\end{array}$ & - & 84.7 & 0.1150202 & 0.2282219 & 0.000000764 & 0.934409 \\
\hline Pistosaurus sp. & & 91.4 & 0.0207013 & 0.0517014 & 0.000000817 & 0.9180916 \\
\hline \multicolumn{7}{|l|}{ Plesiosauria } \\
\hline \multicolumn{7}{|l|}{ Ichthyosauria } \\
\hline $\begin{array}{l}\text { Ichthyosaurus sp. } \\
\text { StIPB R } 222\end{array}$ & Ich & 68 & 0.1273568 & 0.1281216 & 0.0232191 & 0.7214996 \\
\hline $\begin{array}{l}\text { Stenopterygius sp. } \\
\text { SMNS A }\end{array}$ & $\mathrm{St}$ & 54.2 & 0.0307268 & 0.9294553 & 0.471013 & 0.9945984 \\
\hline \multicolumn{7}{|l|}{ Mosasauria } \\
\hline $\begin{array}{l}\text { Dallasaurus turneri } \\
\text { SMU } 76386\end{array}$ & $\mathrm{Da}$ & 89.8 & 0.0516712 & 0.4467431 & 0.5179167 & 0.999999 \\
\hline $\begin{array}{l}\text { Prognathodon sp. } \\
\text { IRScNB } 1624\end{array}$ & $\operatorname{Pr}$ & 46.5 & 0.1007096 & 0.8509145 & 0.251967 & 0.999999 \\
\hline \multicolumn{7}{|l|}{ Crocodylia } \\
\hline Crocodylus sp. & $\mathrm{Cr}$ & 82.3 & 0.0470759 & 0.3662778 & 0.00000026 & 0.9601293 \\
\hline Stenopterygius sp. & & 72.6 & 0.0486055 & 0.5723891 & 0.5651298 & 0.8091993 \\
\hline \multicolumn{7}{|l|}{ Testudines } \\
\hline $\begin{array}{l}\text { Chelonoidea } \\
\text { StIPB R } 409\end{array}$ & $\mathrm{Ch}$ & 72.6 & 0.1031421 & 0.6081272 & 0.349319 & 0.9818974 \\
\hline $\begin{array}{l}\text { Dermochelys coriacea } \\
\text { OMNH unnumbered }\end{array}$ & $\mathrm{De}$ & 56.7 & 0.0441581 & 0.9192567 & 0.4853482 & 0.999999 \\
\hline \multicolumn{7}{|l|}{ Diapsida indet. } \\
\hline $\begin{array}{l}\text { Horaffia kugleri } \\
\text { SMNS } 84816\end{array}$ & - & 86.3 & 0.0077258 & 0.0654034 & 0.000000722 & 0.8672099 \\
\hline $\begin{array}{l}\text { Horaffia kugleri } \\
\text { MHI 2112-1 }\end{array}$ & - & 87.2 & 0.0719306 & 0.0648492 & 0.00000505 & 0.887713 \\
\hline $\begin{array}{l}\text { Horaffia kugleri } \\
\text { MHI } 2112-2\end{array}$ & - & 83.8 & 0.0460113 & 0.1610575 & 0.000000494 & 0.8664546 \\
\hline $\begin{array}{l}\text { Horaffia kugleri } \\
\text { MHI 2112-4 (part) }\end{array}$ & - & 82.7 & 0.0720729 & 0.000001 & 0.000000851164 & 0.8326156 \\
\hline Mammalia & & & & & & \\
\hline
\end{tabular}




\begin{tabular}{|c|c|c|c|c|c|c|}
\hline $\begin{array}{l}\text { Paleoparadoxia sp. } \\
\text { AMP AK0011 }\end{array}$ & Pap & 99.1 & 0.050096 & 0.2083801 & 0.8632984 & 0.9976097 \\
\hline Otariidae StIPB unnumbered & Ot & 75.6 & 0.0916312 & 0.3795253 & 0.000000196 & 0.9150631 \\
\hline Otariidae StIPB unnumbered & Ot & 72.2 & 0.1288439 & 0.4659179 & 0.2728689 & 0.887505 \\
\hline $\begin{array}{l}\text { Phocoena phocoena } \\
\text { MNHNAC 1881-232 }\end{array}$ & $\mathrm{Pp}$ & 42 & 0.0750872 & 0.8726646 & 0.233615 & 0.999999 \\
\hline $\begin{array}{l}\text { Leptonychotes weddellii } \\
\text { NSM M } 29643\end{array}$ & Le & 76.3 & 0.0970976 & 0.7085641 & 0.548983 & 0.999999 \\
\hline $\begin{array}{l}\text { Trichechus manatus } \\
\text { ZFMK } 73223\end{array}$ & $\mathrm{Tm}$ & 84.7 & 0.0495546 & 0.3919578 & 0.071788 & 0.9989915 \\
\hline $\begin{array}{l}\text { Mirounga leonine } \\
\text { Laurin et al. (2011) }\end{array}$ & Ml & 34.8 & 0.102654 & 0.8723616 & 0.1207943 & 0.999999 \\
\hline $\begin{array}{l}\text { Delphinus delphis } \\
\text { MNHN 1880-1310 }\end{array}$ & $\mathrm{Dd}$ & 32.9 & 0.1941883 & 0.7910332 & 0.0264792 & 0.8089076 \\
\hline $\begin{array}{l}\text { Tursiops truncatus } \\
\text { MNHNAC 1978-09 }\end{array}$ & $\mathrm{Tt}$ & 46.2 & 0.0944516 & 0.7790845 & 0.2733049 & 0.7728642 \\
\hline \multicolumn{7}{|l|}{ Femora } \\
\hline \multicolumn{7}{|l|}{ Placodontia } \\
\hline $\begin{array}{l}\text { Psephoderma alpinum } \\
\text { PIMUZ A/III0735 }\end{array}$ & Ps & 78.2 & 0.16647 & 0.502521 & 0.327674 & 1 \\
\hline $\begin{array}{l}\text { Paraplacodus broilii } \\
\text { PIMUZ T } 5845\end{array}$ & $\mathrm{~Pa}$ & 97.9 & 0.02887 & 0.348015 & 0.935841 & 0.98691 \\
\hline $\begin{array}{l}\text { Placodontia indet. } \\
\text { MB.R. } 812\end{array}$ & $\mathrm{P}$ & 75.7 & 0.12631 & 0.222099 & $1.01 \mathrm{E}-07$ & 0.83904 \\
\hline $\begin{array}{l}\text { Placodontia indet. } \\
\text { MB.R. } 961\end{array}$ & $\mathrm{P}$ & 79.3 & 0.2023 & 0.295706 & $6.85 \mathrm{E}-07$ & 0.98121 \\
\hline $\begin{array}{l}\text { Placodontia indet. } \\
\text { SMNS } 54578\end{array}$ & $\mathrm{P}$ & 72.8 & 0.09033 & 0.443579 & 0.209233 & 0.87531 \\
\hline $\begin{array}{l}\text { Placodontia indet. } \\
\text { MB.R. } 814.2\end{array}$ & $\mathrm{P}$ & 75.1 & 0.111339 & 0.317635 & $1.99 \mathrm{E}-07$ & 0.874517 \\
\hline $\begin{array}{l}\text { Placodontia indet. } \\
\text { IGWH } 23\end{array}$ & $\mathrm{P}$ & 83.5 & 0.14266 & 0.408616 & 0.420981 & 0.95714 \\
\hline $\begin{array}{l}\text { Placodontia indet. } \\
\text { SMNS } 84545\end{array}$ & $\mathrm{P}$ & 77.5 & 0.0766466 & 0.1650459 & $9.96 \mathrm{E}-07$ & 0.8117076 \\
\hline \multicolumn{7}{|l|}{ Eosauropterygia } \\
\hline $\begin{array}{l}\text { Anarosaurus heterodontus } \\
\text { Wijk-HO-A568 }\end{array}$ & - & 85.4 & 0.028206 & 0.249154 & $2.17 \mathrm{E}-07$ & 0.914454 \\
\hline Neusticosaurus sp. & - & 94.1 & 0.020479 & 0.100766 & $8.70 \mathrm{E}-07$ & 0.951613 \\
\hline $\begin{array}{l}\text { Nothosaurus sp. } \\
\text { Wijk05-11 }\end{array}$ & - & 85.8 & 0.114946 & 0.243863 & 2.94E-07 & 0.954017 \\
\hline $\begin{array}{l}\text { Nothosaurus sp. } \\
\text { MHI } 279\end{array}$ & - & 70 & 0.03141 & 0.53516 & $3.91 \mathrm{E}-08$ & 0.990768 \\
\hline $\begin{array}{l}\text { Nothosaurus sp. } \\
\text { MHI } 756\end{array}$ & - & 83.5 & 0.063216 & 0.358611 & $2.54 \mathrm{E}-07$ & 0.975223 \\
\hline $\begin{array}{l}\text { Nothosaurus sp. } \\
\text { MHI } 1987\end{array}$ & - & 82.5 & 0.020176 & 0.361545 & 5.09E-07 & 0.952129 \\
\hline Ceresiosaurus calcagnii & & 91 & 0.0095684 & 0.0977743 & $4.44 \mathrm{E}-07$ & 0.9195684 \\
\hline
\end{tabular}




\begin{tabular}{|c|c|c|c|c|c|c|}
\hline from Hugi 2011 & & & & & & \\
\hline $\begin{array}{l}\text { Simosaurus gaillardoti } \\
\text { SMNS } 18689\end{array}$ & & 74.2 & 0.0266378 & 0.4645042 & $1.16 \mathrm{E}-07$ & 0.9519623 \\
\hline $\begin{array}{l}\text { Simosaurus gaillardoti } \\
\text { SMNS } 18038\end{array}$ & & 87.3 & 0.0624372 & 0.2260992 & 3.49E-07 & 0.9331059 \\
\hline $\begin{array}{l}\text { Cymatosaurus sp. } \\
\text { IGWH } 24\end{array}$ & - & 83.9 & 0.019728 & 0.325621 & 5.08E-07 & 0.941592 \\
\hline $\begin{array}{l}\text { Pistosaurus sp. } \\
\text { SMNS } 84825\end{array}$ & $\mathrm{Pi}$ & 89.8 & 0.00532 & 0.051613 & $1.22 \mathrm{E}-06$ & 0.90021 \\
\hline $\begin{array}{l}\text { Pistosaurus sp. } \\
\text { StIPB R } 90\end{array}$ & $\mathrm{Pi}$ & 73.5 & 0.087861 & 0.543595 & 0.1861428 & 0.997228 \\
\hline $\begin{array}{l}\text { Plesiosaurus sp. } \\
\text { StIPB R90 }\end{array}$ & $\mathrm{Pl}$ & 74.7 & 0.0657891 & 0.2948545 & 0.000000148 & 0.8323505 \\
\hline \multicolumn{7}{|l|}{ Ichthyosauria } \\
\hline $\begin{array}{l}\text { Ichthyosaurus sp. } \\
\text { LO } 11904 \mathrm{t}\end{array}$ & Ich & 68.1 & 0.107999 & 0.866764 & 0.563628 & 0.999999 \\
\hline \multicolumn{7}{|l|}{ Crocodylia } \\
\hline $\begin{array}{l}\text { Steneosaurus sp. } \\
\text { SMNS unnumbered }\end{array}$ & Ste & 80.9 & 0.08959 & 0.306159 & $3.89 \mathrm{E}-07$ & 0.919983 \\
\hline $\begin{array}{l}\text { Metriorhynchus sp. } \\
\text { SMNS } 9427\end{array}$ & $\mathrm{Me}$ & 78.9 & 0.038623 & 0.386662 & 1.72E-07 & 0.935684 \\
\hline $\begin{array}{l}\text { Teleosaurid indet. } \\
\text { BHN 2R } 883\end{array}$ & $\mathrm{Te}$ & 83.3 & 0.074591 & 0.364303 & $9.77 \mathrm{E}-08$ & 0.983314 \\
\hline $\begin{array}{l}\text { Alligator mississipiensis } \\
\text { SMNS } 10481\end{array}$ & $\mathrm{Al}$ & 89.1 & 0.075638 & 0.310733 & $6.95 \mathrm{E}-02$ & 0.999999 \\
\hline \multicolumn{7}{|l|}{ Testudines } \\
\hline $\begin{array}{l}\text { Dermochelys coriacea } \\
\text { OMNH unnumbered }\end{array}$ & $\mathrm{De}$ & 64.3 & 0.061635 & 0.779624 & 0.4257667 & 0.999999 \\
\hline \multicolumn{7}{|l|}{ Mosasauria } \\
\hline $\begin{array}{l}\text { Dallasaurus turneri } \\
\text { SMU } 76529\end{array}$ & $\mathrm{Da}$ & 65.1 & 0.022499 & 0.591683 & 0.0194296 & 0.999999 \\
\hline
\end{tabular}




\section{S4. Cross sections of sampled bones transformed into black (medulla and vascular cavities) and white (compact bone) pictures}

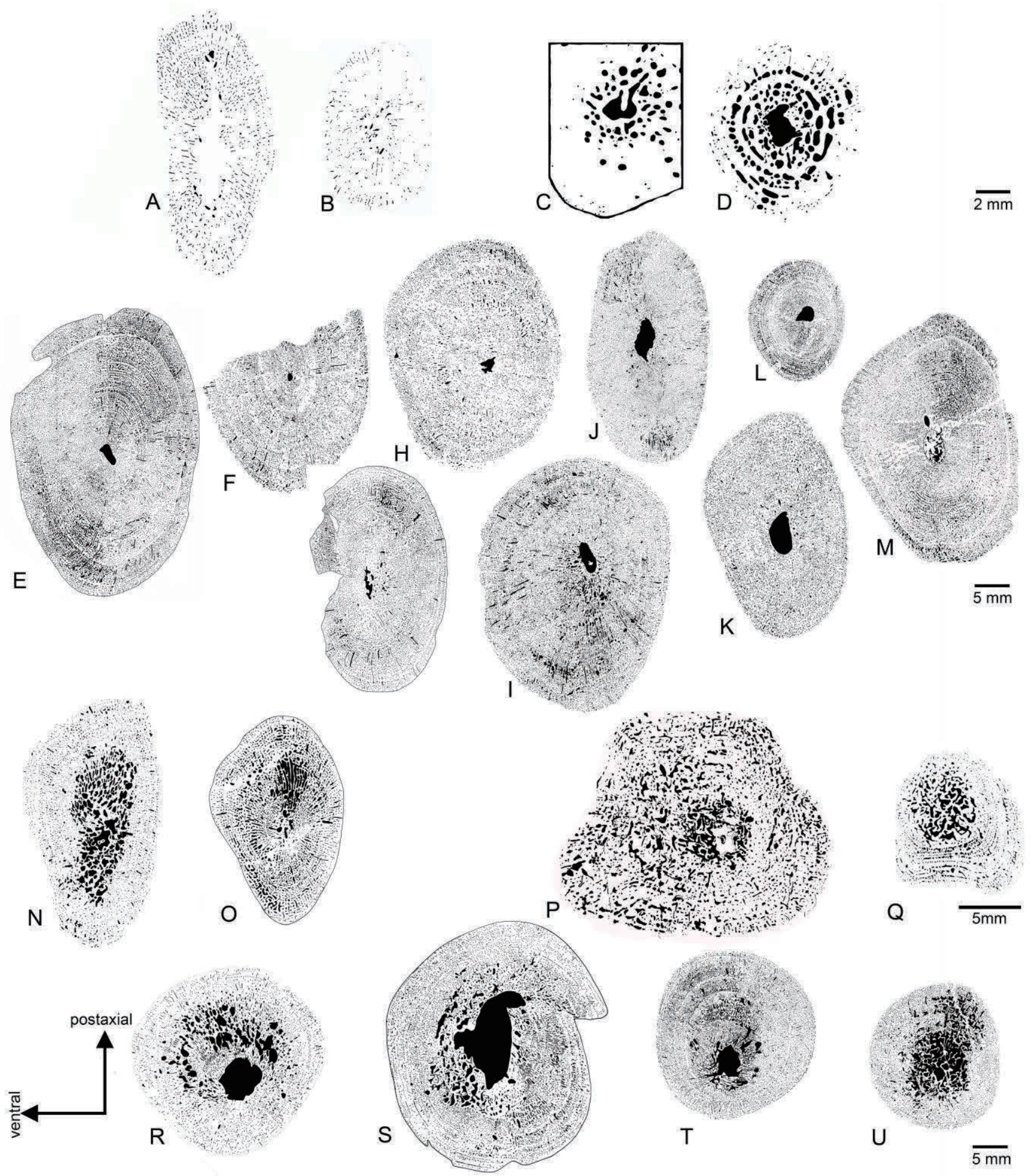

A, Black and white picture of humerus and B, Femur of Paraplacodus broilli (PIMUZ T5845) from the Anisian/Ladinian (Besano Formation, Grenzbitumenhorizont) of the locality of Monte San Giorgio (Switzerland/Italy). Note the lack of a medullary cavity and the low number of vascular canals in both samples. C, Black and white picture of humerus (PIMUZ A/III 1476) and D, Femur (PIMUZ A/III 0735) of Psephoderma alpinum from the Rhaetian (Kössener Formation) of Tinzenhorn (Switzerland). Note the large medullary cavities surrounded by a distinct and large perimedullary region and the nearly avascular cortex. E- 
L, Black and white pictures of humeri of Placodontia indet. aff. Cyamodus from the early Ladinian (Upper Muschelkalk) of southern Germany (see Table 1 for locality information). E, Black and white picture of humerus SMNS 59831. F, Black and white picture of humerus MHI 2112-6. G, Black and white picture of humerus SMNS 15891. H, Black and white picture of humerus SMNS 54569. I, Black and white picture of humerus SMNS 15937. J, Black and white picture of humerus SMNS 54582. K, Black and white picture of humerus MHI 697. L, Black and white picture of humerus MHI 1096. M, Black and white picture of humerus MHI 2112-4 of the marine reptile Horaffia kugleri from the middle Ladinian (Upper Muschelkalk/Keuper Grenzbonebed) of Obersontheim-Ummenhofen (Crailsheim, Baden Württemberg, Germany). Note the small medullary cavities and the high vascularization in humeri of cf. Cyamodus and Horaffia kugleri. N-U Black and white picture of humeri and femora of Placodontia indet. N, Black and white picture of placodont humerus MB.R. 454 from the early Anisian (Lower Muschelkalk) of Ohrdruf (Górny Śląsk, Poland). O, Black and white picture of placodont humerus IGWH 9 from the Anisian (Lower/Middle Muschelkalk) of Freyburg (Unstrut river valley, East-Germany). P, Black and white picture of placodont femur SMNS 84545 from the middle Ladinian (Upper Muschelkalk/Keuper) of Hegnabrunn (Franconia, Bavaria, Germany). Q, Black and white picture of placodont femur IGWH 23 from the Anisian (Lower/Middle Muschelkalk) of Freyburg (Unstrut river valley, East-Germany). Note the medullary and perimedullary regions that are merged into each other in humeri MB.R. 454, IGWH 9 and femora SMNS 84545 and IGWH 23. R, Black and white picture of placodont femur MB.R. 961 from the Ladinian (Upper Muschelkalk) of Bayreuth (Germany). S, Black and white picture of placodont femur MB.R. 814.2 from the early Anisian (Lower Muschelkalk) of Górny Śląsk (Poland). T, Black and white picture of placodont femur MB.R. 812 from the early Anisian (Lower Muschelkalk) of Opatowitz (Górny Śląsk, Poland). U, Black and white picture of placodont femur SMNS 54578 from the early Ladinian (Upper Muschelkalk) of Hegnabrunn (Franconia, Bavaria). Note the de-central medullary cavity and the mainly postaxially oriented trabecular-like bone. 


\section{S5. Histological details of Placodontia}
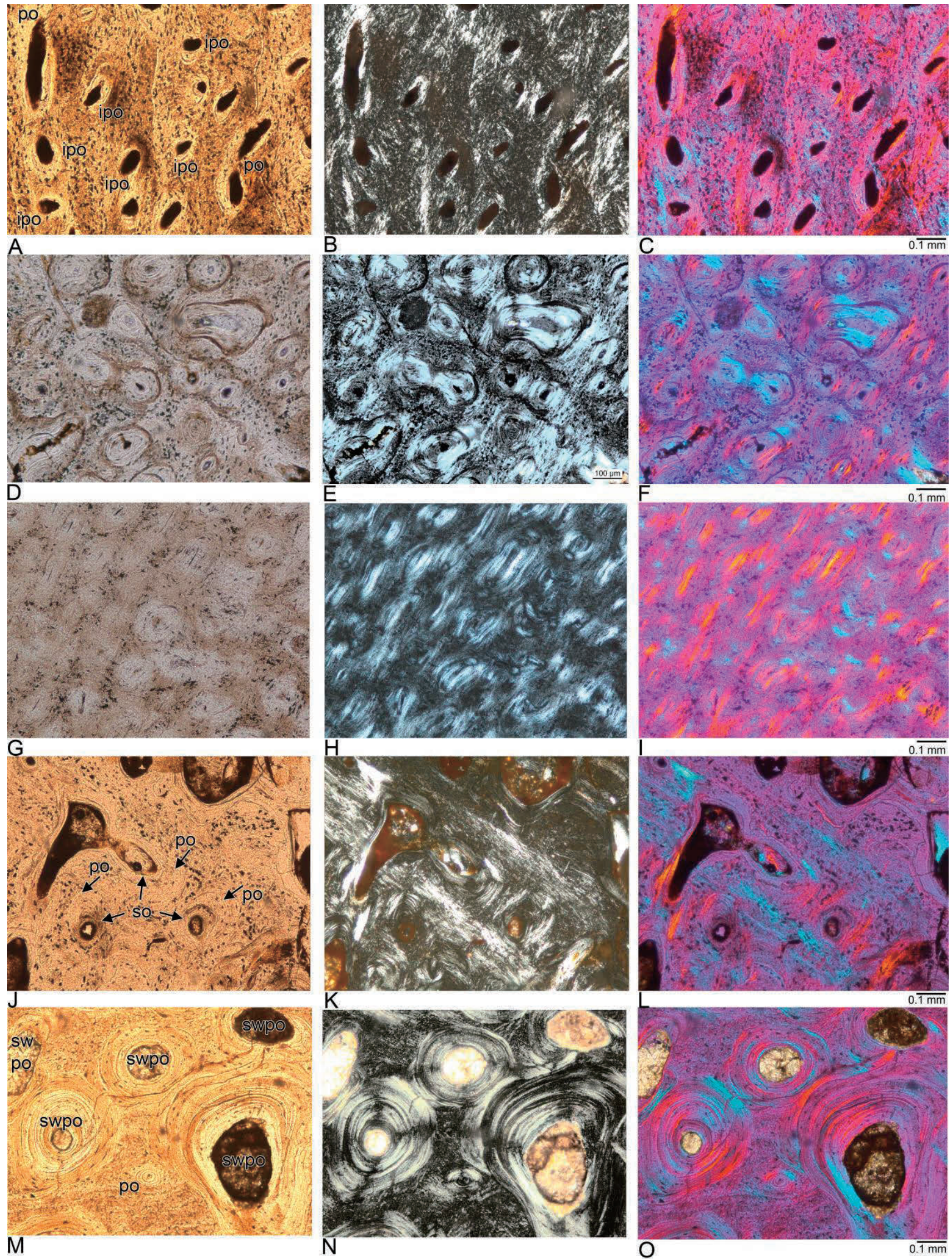
Histological details of Placodontia in normal (left), polarized (middle), and polarized with gypsum light (right). A-C, Immature (incompletely lined) primary osteons in a matrix of coarse parallel-fibred bone in femur MB.R. 814.2 (Placodontia indet.). D-F, Primary and secondary osteons in a matrix of coarse parallelfibred bone in humerus SMNS 54569 (Placodontia indet. aff. Cyamodus). Note the distinct resorption line of the secondary osteons when compared to primary osteons. G-I, Primary osteons in humerus SMNS 54582 (Placodontia indet. aff. Cyamodus). J-L, Erosion of primary osteons by secondary osteons in femur MB.R. 814.2 (Placodontia indet.) in a matrix of coarse parallel-fibred bone. A similar pattern of remodelling was described by Redelstorff et al. 2014 in a long bone of a dinosaur. M-O, Secondarily widened primary osteons in femur SMNS 84545 (Placodontia indet.). Abbreviations: ipo = immature (not completely lined) primary osteons; po $=$ primary osteons; so $=$ secondary osteons; swpo $=$ secondarily widened osteons.

\section{Reference}

Redelstorff R, Sander PM, Galton PM. 2014. Unique bone histology in partial large bone shafts from Upper Triassic of Aust Cliff, England: An early independent experiment in gigantism. Acta Palaeontologica Polonica 59: 607-615. 


\section{S6. Histological details of Placodontia}
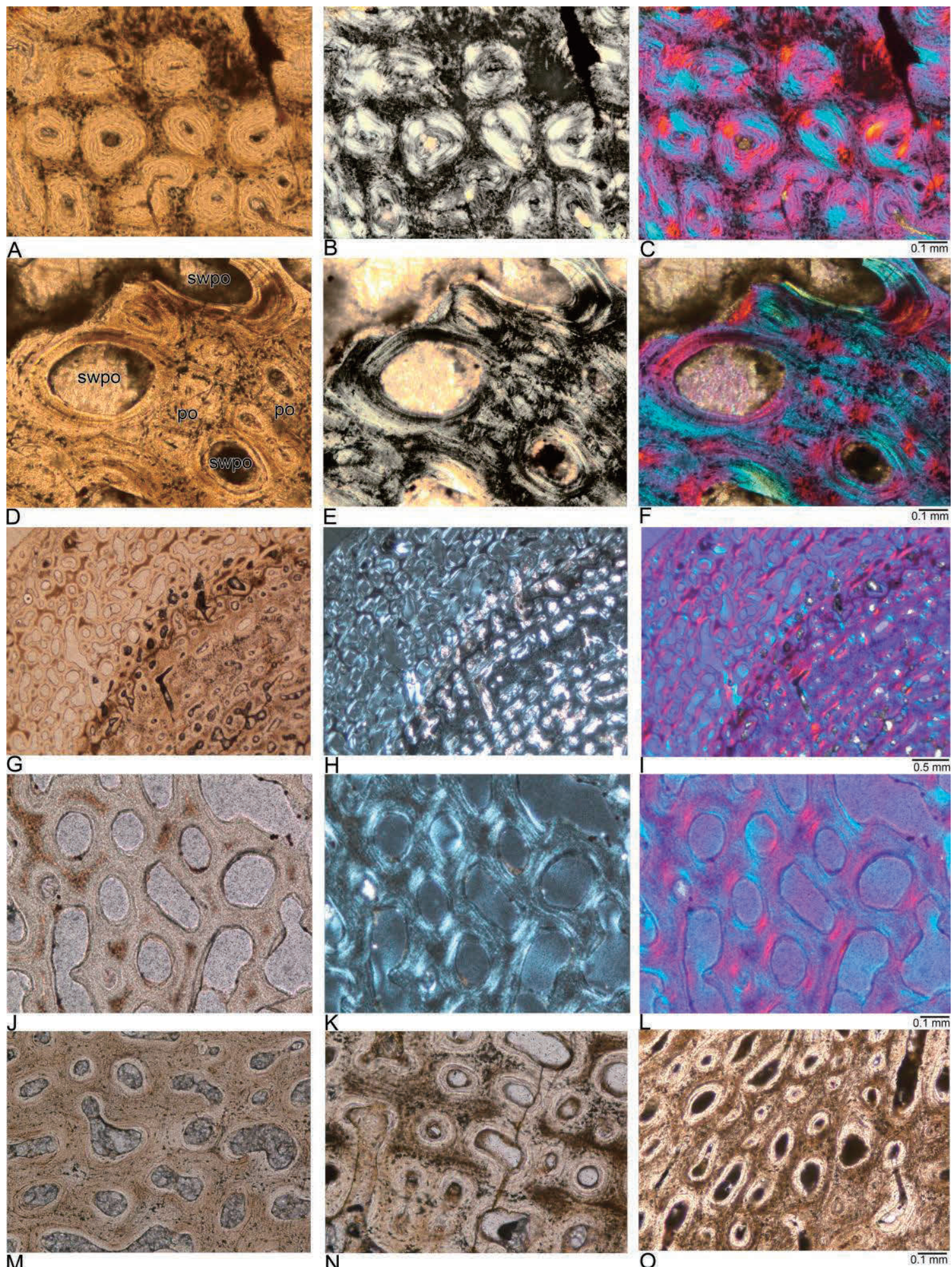

Histological details of Placodontia in normal (left), polarized (middle), and polarized with gypsum light (right). AC, Primary osteons in humerus SMNS 59831 (Placodontia indet. aff. Cyamodus). Note the different appearance of primary osteons when compared to those figured in Suppl. Fig. 3G-I. D-F, Secondarily widened primary osteons in femur MB.R. 961 (Placodontia indet.). G-I, Outer ring of secondarily widened primary osteons in humerus SMNS 54569 (Placodontia indet. aff. Cyamodus). J-L, Enlargment of the same section. M, Secondarily widened primary osteons in humerus SMNS 15937, in humerus MHI 1096, and in humrus MHI 2112-6 (all (Placodontia indet. aff. Cyamodus). 